\title{
Multiple Myeloma and Bone: The Fatal Interaction
}

\author{
Silvia Marino ${ }^{1}$ and G. David Roodman ${ }^{1,2}$ \\ ${ }^{1}$ Department of Medicine, Division Hematology Oncology, Indiana University School of Medicine, \\ Indianapolis, Indiana 46202 \\ ${ }^{2}$ Roudebush VA Medical Center, Indianapolis, Indiana 46202 \\ Correspondence: groodman@iu.edu
}

\begin{abstract}
Multiple myeloma ( $\mathrm{MM})$ is the second-most-common hematologic malignancy and the most frequent cancer to involve bone. MM bone disease (MMBD) has devastating consequences for patients, including dramatic bone loss, severe bone pain, and pathological fractures that markedly decrease the quality of life and impact survival of MM patients. MMBD results from excessive osteoclastic bone resorption and persistent suppressed osteoblastic bone formation, causing lytic lesions that do not heal, even when patients are in complete and prolonged remission. This review discusses the cellular and molecular mechanisms that regulate the uncoupling of bone remodeling in MM, the effects of MMBD on tumor growth, and potential therapeutic approaches that may prevent severe bone loss and repair damaged bone in MM patients.
\end{abstract}

M ultiple myeloma (MM) is the secondmost-common hematological malignancy, with an annual incidence of 5.85/100,000 adults in Western countries (Howlader et al. 2016). Approximately 30,280 new cases will be diagnosed in the United States in 2017 with 12,590 deaths caused by MM (Siegel et al. 2017). The incidence of $M M$ is 2 to 3 times higher in African Americans than in Caucasians (Bhatnagar et al. 2015) with a 5-year survival rate of $48.5 \%$. The incidence of MM increases with age with 70 being the median age at diagnosis, and $2 \%$ of cases are under the age of 40 . The incidence of MM is slightly increased in males compared with females (1.6:1).

MM results from an uncontrolled clonal expansion of neoplastic plasma cells in the bone marrow, the vast majority of which produce monoclonal immunoglobulins detectable in the serum and/or the urine (Kyle and Rajkumar 2004). MM evolves from an indolent, premalignant disease termed monoclonal gammopathy of undetermined significance (MGUS). Approximately $1 \%$ of MGUS patients progress to asymptomatic and later to symptomatic MM per year (Kyle and Rajkumar 2008). Gene expression studies have identified standard and high-risk (20\% of patients) molecular subtypes of MM associated with poor prognosis (LopezCorral et al. 2014; Botta et al. 2016). In rare cases, patients can develop plasma cell leukemia when malignant plasma cells acquire genetic abnormalities that allow them to survive outside the bone microenvironment (Kumar et al. 2014).

Editors: Gerard Karsenty and David T. Scadden

Additional Perspectives on Bone: A Regulator of Physiology available at www.perspectivesinmedicine.org

Copyright (C) 2018 Cold Spring Harbor Laboratory Press; all rights reserved; doi: 10.1101/cshperspect.a031286

Cite this article as Cold Spring Harb Perspect Med 2018;8:a031286 
MM is currently incurable in the vast majority of patients and is the most frequent cancer that involves the skeleton, with $90 \%$ of patients developing bone lesions during the course of their disease (Roodman 2008, 2010). Bone involvement is responsible for the most devastating consequences of MM, including pathological fractures that can occur in $50 \%-60 \%$ of patients, causing debilitating pain (Melton et al. 2005) and increasing mortality risk by up to $20 \%$ (Saad et al. 2007). In addition, MM bone disease (MMBD) can cause hypercalcemia (15\%) (Sternlicht and Glezerman 2015) and spinal cord compression syndromes (5\%) (Molloy et al. 2015), impacting both quality of life and survival of patients.

MMBD is characterized by a profound deregulation of both osteoclastic bone resorption and osteoblastic bone formation. Bone lesions in MM are purely lytic, because of increased local osteoclast (OC) activity adjacent to MM cells accompanied by severely suppressed osteoblast (OB) activity (Giuliani et al. 2006).

This uncoupling of the normal bone remodeling process, whereby increased OC activity is coupled to new bone formation at the sites of bone removal, results in little or no new bone despite increased bone resorption (Roodman 2009). This explains why bone scans, which measure reactive bone formation, underestimate the extent of bone lesions in MM patients (Healy et al. 2011). Moreover, the majority of bone lesions caused by MM do not heal even when the patients are in complete remission because of the persistent suppression of OB activity (Fig. 1) (Roodman 2011).

Current treatments for MMBD such as bisphosphonates and denosumab primarily target bone destruction by OCs and do not increase bone formation. Several bone anabolic agents are in preclinical or clinical trial for MMBD and will be discussed below.

\section{EFFECTS OF MULTIPLE MYELOMA ON THE BONE MICROENVIRONMENT}

The bone microenvironment consists of a mineralized extracellular matrix (ECM) and a cellular compartment in which hematopoietic and

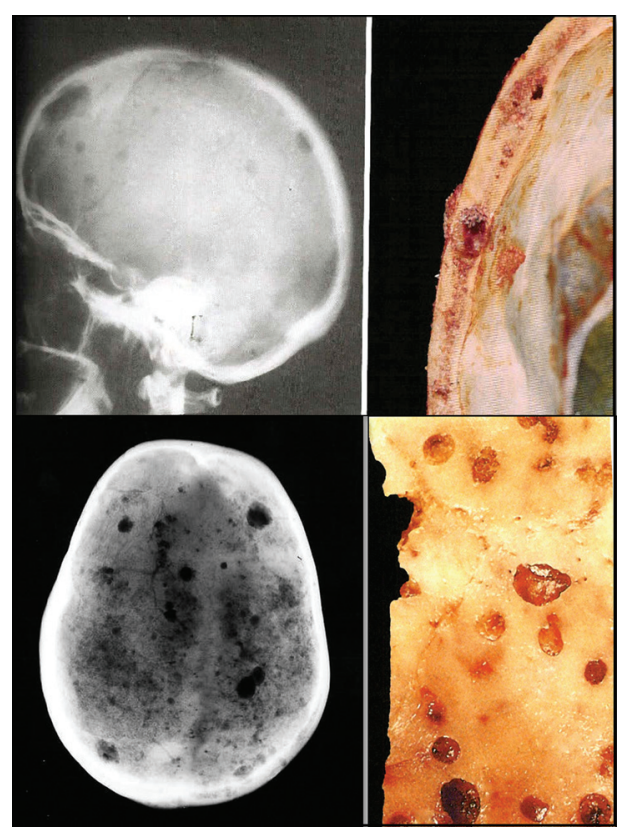

Figure 1. Multiple myeloma bone disease (MMBD) is characterized by excessive bone destruction accompanied by absent new bone formation. In the left panel, the patient has multiple visible tumor lesions in the calvaria as shown by radiography. The right panel shows a segment of skull with myeloma tumor growth in the calvarial bone. (Figure courtesy of Dr. Mankin, Massachusetts General Hospital.)

nonhematopoietic cells reside and is a frequent site for metastasis. Local and systemic mediators, including cytokines, growth factors, hormones, and neural peptides, control the functions of these cells. Sir James Paget proposed the "seed and soil hypothesis" to explain the frequent occurrence of bone metastasis. The bone microenvironment represents a receptive "soil" in which the disseminating cancer cells, "seeds," find a fertile ground that supports their proliferation and expansion (Paget 1889). Tumor cells "home" to bone because they express ligands on their surface that bind to "homing receptors" (e.g., CXCL12 on the surface of bone marrow stromal cells [BMSCs]), a process analogous to hematopoietic stem cells homing to marrow. The increased osteoclastic bone resorption induced by MM tumor cells mobilizes growth factors stored in the bone matrix. These growth factors further stimulate MM cell growth 
and the production of osteolytic and OB-suppressive factors by MM cells and/or cells in the bone microenvironment (Roodman 2004). This vicious cycle promotes and supports MMBD progression and drug resistance.

\section{Mechanisms of Bone Destruction in MMBD}

MM bone lesions are purely lytic, in contrast with breast and prostate cancer patients that develop osteolytic, osteoblastic, or mixed lesions (Mundy 2002). Histological examination of bone biopsies from patients with MMBD showed that bone-resorbing OCs accumulate in close proximity to MM cells as a result of local production of OC-stimulating factors.

MM cells directly stimulate OC formation by releasing a variety of proinflammatory OCactivating factors (OAFs), including receptor activator of nuclear factor $\kappa \mathrm{B}(\mathrm{NF}-\kappa \mathrm{B})$ ligand (RANKL), macrophage inflammatory protein $1 \alpha$ (MIP- $1 \alpha)$, tumor necrosis factor $\alpha$ (TNF$\alpha$ ), interleukin (IL)-3, IL-6, parathyroid hormone-related protein (PTHrP), and hepatocyte growth factor (HGF) (Choi et al. 2000; Frassanito et al. 2001; Giuliani et al. 2004; Lee et al. 2004; Cafforio et al. 2014; Rampa et al. 2014). Moreover, MM cells indirectly increase osteoclastogenesis via interactions with BMSCs, osteocytes, and resident $\mathrm{T}$ cells. Adhesive interactions between $\alpha 4 \beta 1$ integrin on MM cells and vascular cell-adhesion molecule 1 (VCAM-1) on marrow stromal cells promotes the production of stromal-derived RANKL, macrophage colony-stimulating factor (M-CSF), IL-11 and IL-6, and MM-derived MIP-1 $\alpha$, IL-3, and vascular endothelial growth factor (VEGF) (Kumar et al. 2003; Mori et al. 2004; Gunn et al. 2006). MM cell-osteocyte interactions further increase RANKL production by osteocytes.

\section{RANK/RANKL/Osteoprotegerin (OPG)}

The RANK/RANKL signaling pathway represents a major regulator of both normal and pathological bone remodeling. RANKL is a type II homotrimeric transmembrane protein that exists as a membrane-bound or a secreted soluble protein derived by cleavage of the full-length form on the cell surface (Ikeda et al. 2001). In bone, RANKL is mainly expressed by stromal cells, OBs, and osteocytes and is also secreted by activated $\mathrm{T}$ lymphocytes (Anderson et al. 1997; Wong et al. 1997; Wada et al. 2006). Recent studies showed that osteocytes are capable of producing RANKL at 10-fold higher levels than OBs (Nakashima et al. 2011). A number of cytokines and hormones known to stimulate bone resorption (e.g., PTH, 1,25- $\mathrm{OH}_{2} \mathrm{VitD}$, prostaglandins, IL-1 $\beta$, and TNF- $\alpha$ ), increase RANKL expression by OBs (Yasuda et al. 1998; Hofbauer et al. 1999; Hofbauer and Heufelder 2001; Boyle et al. 2003; Takahashi et al. 2014).

RANKL binds its receptor RANK, a type I homotrimeric transmembrane protein with a large cytoplasmic carboxy-terminal domain and an amino-terminal extracellular domain. RANK is a member of the TNF receptor superfamily expressed on the surface of OC precursors and mature OCs. The binding of RANKL to RANK stimulates a number of signaling cascades vital for OC differentiation, survival, and activity (Nakagawa et al. 1998; Hsu et al. 1999; Ehrlich and Roodman 2005).

OPG, a member of the TNF receptor superfamily and soluble decoy receptor for RANKL, is produced by BMSCs and osteocytes and blocks the interaction between RANKL and its receptor on OCs (Simonet et al. 1997; Lacey et al. 1998). The RANKL/OPG ratio is crucial for regulating OC formation and activity (Boyce and Xing 2008).

It is unclear whether MM cells directly produce RANKL or only induce its production by acting on cells in the bone microenvironment. Several studies reported that RANKL is expressed by MM cells in bone marrow biopsies and in human and murine MM cell lines (Sezer et al. 2002a,b; Heider et al. 2003). Recently, Schmiedel et al. (2013) reported that MM cells from patients expressed RANKL and that RANKL was responsible for the release of TNF- $\alpha$, IL- 6 , and IL- 8 via an autocrine/paracrine mechanism that increased the survival and growth of malignant cells and exacerbated bone destruction. Conversely, Giuliani and colleagues found that there was an imbalance between OPG and RANKL that favors OC for- 
mation in bone marrow from MM patients. CD138 $8^{+}$MM cells and MM cell lines did not express RANKL, and the increased RANKL/ OPG ratio occurred only when human MM cells were cocultured with BMSCs (Giuliani et al. 2001, 2004). Regardless of the source of RANKL, an increased RANKL/OPG ratio in MM patients correlated with poor prognosis and reduced survival (Pearse et al. 2001; Terpos et al. 2003). Importantly, preclinical models of MMBD showed that blocking RANKL-induced OC formation, via administration of recombinant OPG or RANK-Fc, significantly decreased osteolytic lesions and tumor growth in mice (Croucher et al. 2001; Yaccoby et al. 2002). These studies suggest the targeting of the RANK/RANKL/ OPG axis in MMBD, and a recent phase III trial of denosumab in MM patients showed its efficacy for controlling skeletal-related events (SREs) in patients with MMBD (Roodman and Dougall 2008; Raje et al. 2017).

MIP-1 $\alpha$. MIP- $1 \alpha$ is a chemotactic chemokine produced mainly by MM cells and OC that plays an important role in the increased OC activity in MM. MIP- $1 \alpha$ enhances cell adhesion and migration and acts as a chemotactic factor for monocytes and OC precursors. MIP$1 \alpha$ directly induces OC formation by binding to the G-protein-coupled receptors CCR1 and/or CCR5 on human OC precursors in an RANKLindependent fashion (Han et al. 2001; Oba et al. 2005; Tsubaki et al. 2010). However, studies using RANK knockout mice showed that MIP- $1 \alpha$ did not increase osteoclastogenesis in this model, suggesting that in mice MIP-1 $\alpha$ 's effects are mediated by RANKL (Oyajobi et al. 2003). Analysis of bone marrow samples from MM patients with extensive bone destruction showed that levels of MIP- $1 \alpha$ are significantly increased in $70 \%$ of the cases, as compared with other hematological malignancies or normal control samples and are associated with decreased patient survival (Choi et al. 2000; Magrangeas et al. 2003). Increased MIP- $1 \alpha$ concentrations were found to positively correlate with bone lesions in 16 out of $18 \mathrm{MM}$ patients (Uneda et al. 2003), and the osteoclastogenic potential of patient marrow plasma was inhibited by an anti-MIP$1 \alpha$-neutralizing antibody (Choi et al. 2000; Abe et al. 2002). In addition, MIP- $1 \alpha$ indirectly increases OC formation by enhancing the activity of RANKL and IL-6 (Oyajobi et al. 2003), and plays a role in the homing of MM cells to the marrow as well as their proliferation, survival, and adhesion to BMSCs via the expression of $\beta 1$ integrins (Choi et al. 2001; Lentzsch et al. 2003; Menu et al. 2006).

In addition to increasing tumor progression and bone catabolic activity, MIP- $1 \alpha$ may also impair OB function. Vallet et al. (2011) reported that treatment of MM-derived mature $\mathrm{OB}$ with MIP-1 $\alpha$ down-regulated osteocalcin expression and osterix modulation, and these effects were partially prevented by the small-molecule CCR1 antagonist, MLN3897, in vitro and in vivo.

Studies in preclinical models of MMBD have shown that blocking CCR1 decreases tumor burden and bone destruction in the murine 5TGM1 model of MMBD (Vallet et al. 2007; Dairaghi et al. 2012) and partially reverses the inhibitory effects of MIP- $1 \alpha$ on OB. Small molecule CCR1 inhibitors are currently under development (Gladue et al. 2010).

TNF- $\alpha$. TNF- $\alpha$ is a member of the TNF family of transmembrane proteins that signals through two receptors, TNFR1 and TNFR2. Binding of TNF- $\alpha$ to its receptor enhances OC differentiation by stimulating a number of signaling pathways. These include NF- $\kappa \mathrm{B}$, mitogen-activated protein kinases (MAPKs), and PI3K/Akt pathways, that enhance the effects of RANKL (Boyce et al. 2005). In OBs, TNF- $\alpha$ inhibits expression of $\mathrm{OB}$ differentiation markers, such as Runx2, Osx, type-1 collagen, osteocalcin, and matrix deposition and induces apoptosis of mature OBs (Abbas et al. 2003; Nanes 2003; Ghali et al. 2010). Therefore, TNF- $\alpha$ in bone exerts a catabolic effect, stimulating bone loss and inhibiting bone formation. Although TNF- $\alpha$ levels are elevated in the bone marrow microenvironment of MM patients with bone diseases, whether MM cells produce sufficient amounts of TNF- $\alpha$ to affect bone is still unclear (Li et al. 2007). Recently, Colucci et al. reported that the soluble decoy receptor 3 (DcR3), a member of the TNF receptor superfamily, is overexpressed by CD $138^{+} \mathrm{MM}$ cells and T cells in patients with MMBD and regulates OC dif- 
ferentiation and survival directly and/or via stimulating the production and release of RANKL and TNF- $\alpha$ by MM T cells (Colucci et al. 2009; Brunetti et al. 2010).

In MM cells, TNF- $\alpha$ induces expression of prosurvival genes, promotes growth, and suppresses apoptosis by activating several pathways, including the NF- $\kappa \mathrm{B}$ pathway (Mitsiades et al. 2002; Bharti et al. 2004; Li et al. 2008). TNF- $\alpha$ is a potent activator of the canonical NF- $\kappa \mathrm{B}$ pathway and is itself regulated through this pathway. However, recent studies by Roy et al. (2017) showed that gain-of-function mutations in components of the noncanonical NF- $\kappa \mathrm{B}$ pathway are responsible for the TNF- $\alpha$-mediated prosurvival activity in $\mathrm{MM}$ cells and confer chemotherapeutic resistance to apoptotic stimuli induced by TNF-related apoptosis-inducing ligand (TRAIL) and other drugs. In addition, TNF- $\alpha$ induces migration of MM cells by activating TNFR2 and up-regulation of monocyte chemoattractant protein (MCP)-1 (Johrer et al. 2004). Furthermore, TNF- $\alpha$ increases the expression of VCAM-1 and the secretion of RANKL and IL- 6 by stromal cells (Hiruma et al. 2009; Teramachi et al. 2016), enhancing stromal cell support of osteoclastogenesis and MM cell growth and increased levels of BAFF and APRIL, TNF-family members, and positively correlates with increased angiogenesis in MM patients (Kumar et al. 2004; Bolkun et al. 2014).

IL-3/Activin A. IL-3 is produced by MM cells and T cells in MM patients and is elevated in bone marrow plasma of $\sim 70 \%$ of MM patients when compared with healthy bone marrow controls. IL-3 contributes to MMBD by affecting both OC-mediated bone resorption and $\mathrm{OB}$ bone formation. Lee and colleagues showed that IL-3 directly enhanced the number of immature OC and cooperates with RANKL and MIP- $1 \alpha$ to increase formation of bone-resorbing OC (Lee et al. 2004). Recently, Silbermann and coworkers (2014) reported that IL-3 induces the production of activin $\mathrm{A}$, a transforming growth factor (TGF)- $\beta$ cytokine member, by macrophages isolated from MM patients, and that activin $\mathrm{A}$ was the mediator for the effects of IL-3 on osteoclastogenesis in vivo. In OB,
Ehrlich and colleagues (2005) showed that IL3 significantly prevented the differentiation of human and murine primary stromal cells into $\mathrm{OB}$ via effects on monocytes/macrophages and inhibited mineralization of mature OB. These data suggest that activin A may be responsible for IL-3-mediated inhibition of OB differentiation and could function as a regulatory molecule in the interaction between $\mathrm{OC}$ and $\mathrm{OB}$ in MMBD (Vallet et al. 2010).

A soluble activin receptor antagonist sotatercept (ACE-011) is currently in phase I clinical trial in combination with lenalidomide and dexamethasone for patients with relapsed and refractory MM (Yee et al. 2015). Sotatercept was reported to inhibit MM cell growth, improve anemia, and increase bone mass (Pearsall et al. 2008; Lotinun et al. 2010).

\section{Semaphorin 4D}

Semaphorin 4d (Sema4D) is produced by MM cells and OC (Dacquin et al. 2011; Terpos et al. 2012 b) and increases OC activity and suppresses $\mathrm{OB}$ differentiation and motility by binding to its receptor plexin-B1 (Negishi-Koga et al. 2011). Terpos et al. (2012b) showed that Sema4D and plexin-B1 levels are increased in MM patients. Recent studies have shown that coculture of MM cells with mouse bone increased Sema4D expression in both and that osteocytes were a major source of Sema4D (Suvannasankha et al. 2016). A Sema4D antibody is currently in clinical trial for breast cancer bone metastasis (Patnaik et al. 2016).

PTHrP. PTHrP is a secreted factor, functionally analogous to PTH, the major regulator of calcium homeostasis (Murray et al. 2005). PTHrP acts as an autocrine, paracrine, or intracrine factor in a number of developmental, physiological, and pathological processes (Karaplis and Goltzman 2000; Liao and McCauley 2006; Kremer et al. 2011; Foley et al. 2012; Rosen 2013). PTHrP plays a key role in osteolytic metastases, and is produced by a variety of different solid tumor cells that metastasize to bone (Guise et al. 1996; Li et al. 2011; Soki et al. 2012). Several studies reported that serum levels of PTHrP are increased in MM patients with hypercalcemia 
and osteolytic bone disease compared with MGUS patients or normal donors. These studies showed that PTHrP is produced and secreted by MM cells, increases tumor survival and proliferation, and enhances MM production of osteoclastogenic factors such as RANKL and MCP-1 (Kitazawa et al. 2002; Cafforio et al. 2014). Moreover, PTHrP induces the expression of $\mathrm{E} 4 \mathrm{BP} 4$, an osteoblastic transcriptional repressor gene, exacerbating bone damage (Silvestris et al. 2008).

Adhesive Interaction. Adhesive interactions between MM cells and BMSCs and components of the marrow ECM play a central role in MMBD. Interactions between MM and BMSCs through the binding of adhesion molecules on BMSCs and members of the integrin family on MM cells are involved in MM cell homing, survival, proliferation, and drug resistance via a mechanism mediated by both physical binding and cytokine release (reviewed in Katz 2010). These adhesive interactions activate survival pathways in MM cells, such as NF- $\mathrm{KB}$ and p38 MAPK (Hideshima et al. 2003; Annunziata et al. 2007; Vanderkerken et al. 2007; Tornatore et al. 2014). Activation of these pathways in BMSCs is responsible for their production of osteoclastogenic and angiogenic factors (RANKL, IL-6, and VEGF) that increase OC formation, angiogenesis, and MM survival, contributing to the bone destructive process (Roodman 2002).

We and others recently reported that the adaptor protein p62 may represent a viable target for the treatment of MMBD. P62 is a multidomain adaptor protein that has no enzymatic activity but serves as a platform for the formation of multiple signaling complexes involved in MM cell growth, OC formation, and $\mathrm{OB}$ activity. The p62 protein is composed of six domains, including an atypical protein kinase $\mathrm{C}$ (aPKC)interacting domain (PB1) that serves as a p62 dimerization domain, the $\mathrm{ZZ}$ zinc finger that binds to the TNF- $\alpha$ signaling adaptor receptor interacting protein (RIP), a p38 and LIM interaction domain, a TBS domain for binding to TRAF6, an LIR domain involved in autophagy, and a UBA domain that mediates noncovalent interactions with ubiquitin (reviewed in Moscat et al. 2007; Lippai and Low 2014).
Studies in OC precursors conducted by our group found that increased p62-mediated signaling increases OC formation in vitro and in vivo (Kurihara et al. 2007; Hiruma et al. 2008). Moreover, measurement of p62 and aPKC levels in stromal cells from MM patients showed that activation of aPKC was significantly increased in MM patient stromal cells compared with healthy donors, whereas the levels of p62 were similar. To further characterize the role of p62 in MM, we knocked down p62 in healthy donor and patient stromal cells and found that aPKC and VCAM-1 expression and IL- 6 production were significantly decreased, reducing stromal cell support of MM cell growth. Further, p62 knockdown markedly decreased TNF- $\alpha$ mediated activation of NF- $\kappa \mathrm{B}$ and p38 MAPKmediated signaling and RANKL expression compared with control stromal cells. Importantly, coculture of healthy OC precursor and p62-deficient stromal cells impaired osteoclastogenesis in response to TNF- $\alpha$ and IL-6, factors that play a central role in MMBD (Hiruma et al. 2009). We recently reported that pharmacologic inhibition of the p62-ZZ domain by the novel small molecule antagonist (XRK3F2) inhibited primary CD $138^{+} \mathrm{MM}$ cells and human MM cell line growth by inducing apoptosis without affecting BMSC survival. XRK3F2 treatment of MM cells did not alter their production of TNF- $\alpha$ and IL-7, known OB inhibitory factors, but XRK3F2 blocked TNF- $\alpha$ induced PKC and NF- $\mathrm{KB}$ activation in stromal cells and partially down-regulated their production of IL- 6 and RANKL. More importantly, in vivo studies showed that XRK3F2 induced new bone formation in areas adjacent to MM cells but did not alter non-tumor-bearing bone. This suggests that XRK3F2 allowed MM-exposed $\mathrm{OB}$ to respond to OC-anabolic stimuli and that $\mathrm{OC}$ activity may be required for the anabolic effects of XRK3F2 (Fig. 2) (Teramachi et al. 2016).

These studies suggested that $\mathrm{p} 62$, by regulating multiple signaling pathways involved in inflammation, tumorigenesis, osteoclastogenesis, adipogenesis, and T-cell differentiation, represents a potential target that can be exploited for the treatment of MMBD. Combined inhibition 



Figure 2. The adaptor protein p62 may represent a viable target for the treatment of multiple myeloma bone disease (MMBD). (Left panel) Microcomputed tomography $(\mu \mathrm{CT})$ and $\mathrm{x}$-ray analysis of tibia injected with mouse 5TGM1-myeloma cells showing significant lytic bone destruction. Representative histological sections show infiltration of plasma cells in the marrow space and no evidence of new bone formation. (Right panel) A novel small molecule p62-ZZ domain antagonist XRK3F2 induced new periosteal woven bone formation and increased cortical bone. Interestingly, histological examination of the tibia shows evidence of new bone formation in areas adjacent to multiple myeloma (MM) cells. TRAP staining shows osteoclasts (OCs) and active bone remodeling in the newly formed bone. This suggests that the anabolic effects seen with XRK3F2 may require bone-resorbing OC activity allowing MM-exposed osteoblasts (OBs) to respond to OC-derived anabolic stimuli. Scale bars, $100 \mu$. (From Teramachi et al. 2016; adapted and modified, with permission, from Nature Publishing Group.)

of p62 with other more conventional therapies for MM may have a significant therapeutic effect on MMBD (Milan et al. 2015).

\section{Mechanism of Osteoblastic Suppression in $M M B D$}

Suppression of osteoblastic bone formation plays a critical role in MMBD (Roodman 2011). MMBD is characterized by generalized bone loss and inability of the $\mathrm{OB}$ to repair the osteolytic lesions even when the tumor cells are no longer present in the bone marrow or patients are in long-term remission. Both soluble factors and physical contact between $\mathrm{OB}$ progenitors and $\mathrm{MM}$ cells are responsible for the suppression of $\mathrm{OB}$ differentiation and increase in OB apoptosis in MMBD (Silvestris et al. 2004; Giuliani et al. 2005). BMSCs from MM patients have a severely impaired capacity to differentiate into functional $\mathrm{OB}$ and express a distinct genomic profile when compared with healthy donors (Garayoa et al. 2009). It is still unclear whether BMSCs from MM patients are permanently functionally compromised even in the absence of MM cells, or whether the presence of MM cells is required to affect their function (Yaccoby et al. 2006; Kassen et al. 2014). The inhibitory effects of MM cells on $\mathrm{OB}$ differentiation is caused by their ability to suppress the activity and function of the transcription factor Runx $2 /$ Cbfal in mesenchymal and osteoprogenitor cells (Giuliani et al. 2005). Giuliani and colleagues showed that MM patients that present with osteolytic lesions exhibited a reduction in the number of Runx2-positive OBs compared with patients without MMBD. They showed that inhibition of Runx2 in OB progenitors was mediated by direct cell-cell interaction via the very late antigen (VLA)- 4 on MM cells and VCAM-1 on OB. They showed that a neutralizing VLA-4 antibody reduced the inhibitory effects of MM cells on Runx2/Cbfal activity (Giuliani et al. 2005). Soluble factors produced by MM cells also contribute to Runx2 suppression.

IL-7 and TNF- $\alpha$. In vivo studies have shown that IL-7 suppresses OB differentiation, prevents bone formation, and induces bone loss (Weitzmann et al. 2002; Toraldo et al. 2003). IL-7 levels are increased in the marrow of MM patients, and neutralizing antibodies to IL-7 partially reduces $\mathrm{OB}$ suppression by preventing MM-induced down-regulation of Runx2/Cbfal transcriptional activity, without affecting its 
production (Giuliani et al. 2005). Recently, we showed that IL-7 can also induce the growth factor independent 1 transcriptional repressor (Gfi-1), a repressor of the Runx2 gene transcription that potentiates the effects of TNF- $\alpha$ on OB suppression (D'Souza et al. 2011). The role of Gfi-1 is discussed below.

Dikkopf-1 (DKK1). Wnt signaling has been reported to regulate $\mathrm{OB}$ proliferation and survival (Baron and Kneissel 2013). However, other investigators showed that canonical Wnt signaling is only involved in $\mathrm{OB}$ differentiation during development, but does affect OC differentiation in mature animals by regulating OPG production by $\mathrm{OB}$ and osteocytes (Glass et al. 2005; Kramer et al. 2010). Tian and coworkers reported that DKK1 was expressed by MM cells and acted as a major inhibitor of OB differentiation in MMBD. They further found that DKK1-expression levels correlated with the presence of osteolytic lesions in MM patients (Tian et al. 2003). In vitro, DKK1 acts as an extracellular antagonist of canonical Wnt signaling, preventing the binding of Wnt to the low-density lipoprotein receptor-related protein (LRP) 5/6, ultimately down-regulating Runx2 activity (Gaur et al. 2005; Takada et al. 2007; Zhou et al. 2013). The expression of a number of Wnt inhibitors is increased in $\mathrm{CD}_{138^{+}}$plasma cells from MM patients compared with plasma cells from MGUS patients or normal donors, and their expression is further increased in patients with MMBD compared with MM patients without skeletal lesions (Tian et al. 2003; Giuliani et al. 2007b; Kaiser et al. 2008). Recently, Bolzoni et al. (2013) showed that the expression of coreceptors for the noncanonical Wnt pathway, FZD5 and ROR2, which are up-regulated during osteogenic differentiation, are reduced in BMSCs and pre-OB from MM patients compared with healthy donors. Moreover, treatment of MM patient stromal cells with Wnt5a, or overexpression of ROR2, enhanced their osteogenic differentiation, suggesting a potential involvement of the noncanonical Wnt pathway in MMBD (Bolzoni et al. 2013). In addition, elevated DKK1 levels can promote osteoclastogenesis and bone resorption by modulating RANKL and $\mathrm{OPG}$ expression in $\mathrm{OB}$, suggesting that in- hibition of Wnt signaling in $\mathrm{OB}$ indirectly increases OC (Glass et al. 2005; Spencer et al. 2006; He et al. 2012). Preclinical studies reported that systemic administration of anti-DKK1 antibody inhibited stromal-cell support of MM cell growth, increased trabecular bone formation, and blocked osteoclastogenesis in the severe combined immunodeficiency (SCID)-hu murine model of MMBD (Yaccoby et al. 2007; Fulciniti et al. 2009). The BHQ880 anti-DKK1 antibody has been tested in patients with MM, in combination with approved anti-MMBD therapy, such as zoledronic acid. The results of the study showed that BHQ880 was well tolerated and may be beneficial in patients with relapsed or refractory MM (Iyer et al. 2014).

Sclerostin. Sclerostin has been reported to be an inhibitor of the canonical Wnt signaling pathway produced by osteocytes that suppress $\mathrm{OB}$ proliferation and differentiation (van Bezooijen et al. 2005; Delgado-Calle et al. 2017b). Several studies showed that sclerostin is also produced by MM cells and is elevated in sera of MM patients. High serum sclerostin levels correlated with advanced MMBD and poor patient survival (Brunetti et al. 2011; Colucci et al. 2011; Terpos et al. 2012a). In vitro studies found that sclerostin is in part responsible for the MMmediated reduction of OB-specific proteins (e.g., alkaline phosphates, collagen type 1, bone sialoprotein-II, and osteocalcin) and increased RANKL production in OB, with consequent inhibition of bone formation and increased osteoclastogenesis. A recent in vivo study showed that administration of a neutralizing monoclonal antisclerostin antibody, alone or in combination with conventional anti-MM therapy, significantly reduced tumor burden (Eda et al. 2016). We and others recently reported that antisclerostin antibody treatment increases bone mass and reduces osteolytic lesions in an immunocompetent model of established MM disease, without affecting tumor cell growth in vivo. Moreover, total deletion of the Sost gene in immune-deficient SCID mice prevented development of MM-induced bone lesions (DelgadoCalle et al. 2017a; McDonald et al. 2017).

In addition, osteocyte apoptosis has recently been shown to contribute to MMBD. Giuliani 
and colleagues reported that bone biopsies from MM patients had significantly fewer viable osteocytes when compared with control patients, with increased numbers of dead osteocytes and empty lacunae (Giuliani et al. 2012). Osteocytes are the main source of RANKL (Nakashima et al. 2011; Xiong and O'Brien 2012), and osteocyte apoptosis increases osteocytic RANKL production (Plotkin et al. 2015). We recently found that MM cells increase osteocyte apoptosis via cell-cell contact and/or release of soluble factors by activating the Notch and TNF- $\alpha$ signaling pathways in osteocytes. Osteocyte apoptosis, in turn, increased osteocytic RANKL expression, which induced recruitment of OC precursors and osteoclastogenesis. Moreover, physical interaction between MM cells and osteocytes up-regulated the expression of Sost/ sclerostin in osteocytes that, in turn, inhibited OB differentiation mediated by $\mathrm{Wnt} / \beta$-catenin signaling. These results suggest that osteocytes are responsible for the increased sclerostin concentrations in the MM microenvironment (Delgado-Calle et al. 2016). Eda et al. (2016) suggested that MM cells also stimulate sclerostin expression in immature OBs via a mechanism that is at least in part regulated by DKK1 secreted by MM cells and contribute to impaired $\mathrm{OB}$ differentiation in MM. Further, physical contact of MM cells with osteocytes modifies the Notch receptor repertoire expressed on MM cells and osteocytes, resulting in Notch-mediated MM cell proliferation (Delgado-Calle et al. 2016). A phase III trial of romosozumab, a monoclonal antibody that binds sclerostin, showed that romosozumab increased bone formation, decreased bone resorption, and reduced the risk of vertebral fractures in postmenopausal women with osteoporosis (Cosman et al. 2016).

The suppression of bone formation persists even when MM cells are eradicated and can no longer affect $\mathrm{OB}$ through direct interactions or release osteoblastic inhibitory soluble factors.

Although acquired genetic abnormalities in plasma cells are the primary cause of myeloma, recent studies suggest that epigenetic changes play a critical role in the progression of $\mathrm{MM}$ and may be exploited as a therapeutic target for the treatment of MMBD (reviewed in Issa et al. 2017). Changes in DNA methylation, histone modification, and expression of noncoding RNA can contribute to the pathogenesis of MM (reviewed in Dimopoulos et al. 2014).

As noted above, we recently reported that Gfi-1 induces long-term suppression of OB differentiation in MM. Using chromatin immunoprecipitation analyses (ChIP), we found that MM cells induce epigenetic histone modifications in $\mathrm{OB}$ by converting the Runx2-P1 promoter locus from a poised bivalent state to a repressed state, thereby preventing $\mathrm{OB}$ differentiation. We previously found that MM cells suppress $\mathrm{OB}$ differentiation by inducing the Runx2-transcriptional repressor Gfi-1 in OB precursors. Gfi-1 has multiple binding sites at the Runx 2 promoter and its direct interaction with Runx 2 promoter blocks Runx 2 expression. Moreover, we showed that Gfi-1 recruits histone modifiers (HDAC1, LSD1, and EZH2) to the Runx2 promoter, which decreases H93K9ac and $\mathrm{H} 3 \mathrm{~K} 4 \mathrm{me} 3$ and increases H3K27me3 modification that are essential steps for Runx 2 repression. These repressive chromatin changes in Runx2 persist even after removal of MM cells. ChIP analysis also revealed that BMSCs from MM patients have decreased H93K9ac but showed no significant difference in $\mathrm{H} 3 \mathrm{~K} 27 \mathrm{me} 3$ when compared with healthy stromal cells. Knockdown of Gfi-1 or selective pharmacological inhibition of HDAC1 and EZH2 activity in pre-OB prevented repression of Runx 2 and other $\mathrm{OB}$ differentiation markers induced by $\mathrm{MM}$ and rescued $\mathrm{OB}$ differentiation. These data suggest that treatment of MM patients with clinically available $\mathrm{HDAC} 1$ and $\mathrm{EZH} 2$ inhibitors might be beneficial in reversing the profound $O B$ suppression associated with MM, allowing the repair of osteolytic lesions (Fig. 3) (Adamik et al. 2017).

Preliminary studies in our laboratory recently showed that a p62-ZZ domain small molecule inhibitor, XRK3F2, prevented MM-induced Gfi-1 binding to Runx2 promoter and recruitment of the chromatin corepressor HDAC1. Moreover, ChIP analysis of BMSCs from MM patients showed that XRK3F2 rescued $\mathrm{H} 3 \mathrm{~K} 9 \mathrm{ac}$ levels at the Runx2 promoter but had no 



Figure 3. Schematic representation of sustained suppression of osteoblast (OB) differentiation caused by epigenetic repression of Runx2 gene transcription in multiple myeloma (MM)-exposed pre-OBs. MM down-regulates Runx2/Cbfa1 transcriptional activity in pre-OBs by inducing the growth factor independent 1 transcriptional repressor (Gfi-1). Gfi-1 blocks Runx2 gene transcription and potentiates the effects of tumor necrosis factor $\alpha$ (TNF- $\alpha$ ) on OB suppression and bone formation. Gfi- 1 binds to Runx 2 and facilitates recruitment of the histone corepressors HDAC1, LSD1, and EZH2, resulting in H3K27 methylation of the promoter, and thus blocks transcriptional activation in response to $\mathrm{OB}$ differentiation stimuli. Inhibition of either HDAC1 or EZH2 can reverse this inhibition of Runx2 and allow OB differentiation. (From Adamik et al. 2017; adapted and modified, with permission, from the American Association for Cancer Research.)

effect on $\mathrm{H} 3 \mathrm{~K} 9 \mathrm{ac}$ levels in healthy donors. These results suggest that targeting the p62 ZZ domain may be of value in reversing MM-induced epigenetic suppression of Runx2 in MM stromal cells, allowing restoration of $\mathrm{OB}$ function in patients with MMBD (Silbermann et al. 2016).

\section{EFFECTS OF THE BONE MICROENVIRONMENT ON MULTIPLE MYELOMA CELLS}

MM cell proliferation and survival rely on factors produced by cells of the bone microenviron- ment. Physical interaction of MM cells with BMSCs and osteocytes activates proliferative and antiapoptotic pathways in MM cells and induces BMSC secretion of factors such as IL6 , VEGF, and insulin-like growth factor (IGF)-1 that stimulate MM cell growth and survival. Recently, several studies reported that BMSCs release exosomes containing microRNA (miRNA) that are transferred to MM cells, resulting in miRNA-mediated increased MM proliferation, survival, and drug resistance (Roccaro et al. 2013; Wang et al. 2014). OCs also produce a number of factors that directly enhance cell growth and prevent MM apoptosis, such as IL6 
and AXII (Roodman 1999; Abe et al. 2004; Yaccoby et al. 2004; Bao et al. 2009). We and others recently reported that OCs act as angiogenic cells and can contribute to the increased microvessel density that characterizes MM and correlates with disease progression (Pruneri et al. 2002; Rajkumar et al. 2002; Giuliani et al. 2011). In vitro studies by Tanaka and coworkers (2007) showed a mutual stimulatory process between angiogenesis and osteoclastogenesis via the production of MM-derived VEGF and OCderived osteopontin that contributes to enhance new vessel formation and could be blocked by anti-VEGF or antiosteopontin treatments. In our studies, however, recombinant osteopontin did not affect angiogenesis, suggesting that other factors are involved. Our studies, using a combination of ex vivo and in vivo models, suggested that OCs stimulate angiogenesis via the secretion of MMP-9, and lack of MMP-9 decreased OC number in vivo in response to PTHrP or RANKL, most likely the result of suppression of OC migration (Cackowski et al. 2010). In addition, osteoclastic bone resorption releases immobilized growth factors from the matrix such as IGF-1, fibroblast growth factor (FGF), and TGF- $\beta$, which promote MM cell growth (Mahtouk et al. 2010).

Recent evidence suggests that adipocytes also play a role in MM. The dynamic interplay between $\mathrm{OB}$, marrow adipocytes, and bone marrow adiposity could create a favorable microenvironment in which $\mathrm{MM}$ can engraft and grow, thereby contributing to MMBD. In vitro studies showed that adipocytes support MM cell proliferation and prevents chemotherapy-induced apoptosis by releasing factors such as IL-6, TNF- $\alpha$, MCP-1, and insulin to support MM expansion and promote disease progression (Carson et al. 2014; Liu et al. 2015). The adipokine, adiponectin, reduces MM proliferation and induces MM cell death (Medina et al. 2014), and reduced circulating levels of adiponectin were found in MGUS patients that developed symptomatic MM (Fowler et al. 2011; Hofmann et al. 2012). Moreover, Fowler et al. (2011) recently showed that marrow adiponectin gene expression and adiponectin serum protein levels were significantly reduced in the MM-permis- sive C57Bl6/KaLwRij mice, compared with the nonpermissive, but closely related C57B16/J mice. These investigators also found that pharmacological stimulation of adiponectin in tumor-bearing mice decreased tumor burden and increased survival, showing the potential usage of increasing adiponectin for treatment of MMBD (Fowler et al. 2011).

MM profoundly modifies the immune function of the bone marrow microenvironment. $\mathrm{T}$ cells are known to modulate bone cell differentiation, survival, and activity (Lorenzo et al. 2008; D'Amico and Roato 2012). Several studies reported that $\mathrm{CD} 4^{+}$regulatory T cells producing IL-17 are increased in the bone marrow of MM patients (Dhodapkar et al. 2008; Noonan et al. 2010; Prabhala et al. 2010). IL-17 has been implicated in MM cell survival as well as lytic bone destruction, independent of its effect on tumor cells. Moreover, IL-6, which is abundant in the MM marrow microenvironment, plays a critical role in the differentiation of $\mathrm{CD} 4^{+} \mathrm{T}$ cells toward the Th17 lineage. This occurs via TGF- $\beta$ activation of the retinoic acid-related orphan receptor $\gamma \mathrm{t}$ (ROR $\gamma \mathrm{t}$ ) (Fig. 4) (Zou and Restifo 2010; Basu et al. 2013).

\section{THERAPEUTIC TARGETING OF MULTIPLE MYELOMA BONE DISEASE}

Treatment of MMBD is complex and requires the simultaneous management of tumor proliferation, increased bone destruction, and persistent suppression of bone formation. Further, MMBD is incurable and current management uses a combination of chemotherapy, localized radiotherapy, and surgery.

\section{Bisphosphonates}

Bisphosphonate therapy remains the standard care for the management of MMBD (Pozzi and Raje 2011). Pamidronate, zoledronic acid, and clodronate are the most commonly used bisphosphonates for treatment of myeloma-induced SREs, and to reduce new osteolytic lesions, new pathological fractures, and hypercalcemia (Kyle et al. 2007; Terpos et al. 2009). Bisphosphonate treatment also improves bone 




Figure 4. Cellular communication and interplay in the bone microenvironment of multiple myeloma bone disease (MMBD). Interplay among the cells of the bone marrow microenvironment is responsible for the excessive bone destruction and abnormal bone remodeling that characterizes MMBD. Myeloma cells directly stimulate osteoclast (OC) formation through the production of OC-activating factors (OAFs) such as receptor activator of nuclear factor $\kappa B$ ligand (RANKL), macrophage inflammatory protein $1 \alpha$ (MIP-1 $\alpha$ ), interleukin (IL)-3, tumor necrosis factor $\alpha$ (TNF- $\alpha$ ), semaphorin 4d (Sema4D), and parathyroid hormone-related protein (PTHrP). Physical interactions between myeloma cells and marrow stromal cells increase release of factors from marrow stromal cells that enhance osteoclastogenesis, including RANKL, macrophage colony-stimulating factor (M-CSF), IL-6, and TNF- $\alpha$, and decrease production of OC inhibitory factors, such as osteoprotegerin (OPG). Newly formed OCs secrete soluble factors such as osteopontin, MIP-1 $\alpha$, IL-6, AXII, BAFF, and APRIL, which stimulate tumor growth and increase bone destruction. Bone resorption releases matrix-associated growth factors such as transforming growth factor (TGF)- $\beta$, insulin-like growth factors (IGFs), fibroblast growth factor (FGF), platelet-derived growth factors (PDGFs), and bone morphogenetic proteins (BMPs), which increase myeloma cell proliferation, exacerbating the osteolytic process. Myeloma cells also induce osteocyte apoptosis that upregulates osteocyte expression of RANKL. Myeloma cells also induce profound suppression of bone formation by myeloma-derived osteoblast (OB)-inhibitory factors that include Dikkopf-1 (DKK1), sclerostin, hepatocyte growth factor (HGF), IL-7, and TNF- $\alpha$. Bone formation is further suppressed by myeloma-induced release of sclerostin from osteocytes and TNF- $\alpha$ from marrow stromal cells. Myeloma cells also induce marrow stromal cells to produce factors including IL-6, vascular cell-adhesion molecule 1 (VCAM-1), vascular endothelial growth factor (VEGF), and IGF-1 that enhance myeloma cell proliferation. Angiogenesis is also enhanced in MMBD, by increased OC and bone marrow stromal cell (BMSC) secretion of angiogenic factors, such as osteopontin, MMP9, and VEGF.

pain through inhibition of OC activity. Recently, Hiasa et al. (2017) reported that zoledronic acid in combination with selective V-ATPase inhibitor and acid-sensing nociceptor inhibitor significantly reduced MM-induced bone pain in a murine model of MM, by preventing the acidi- fication of the bone microenvironment by proton-secreting OC. However, bisphosphonate treatments only decrease SREs by $50 \%$ and the major complication associated with the therapy is osteonecrosis of the jaw (Van den Wyngaert et al. 2007). 


\section{DENOSUMAB}

Denosumab, a highly specific human monoclonal antibody that binds to RANKL and prevents its binding to the RANK receptor on OC, was approved by the Food and Drug Administration (FDA) for the management of bone metastases associated with solid tumors. A phase III trial of denosumab versus zoledronate for MMBD was recently completed. Data from a randomized double-blind study of denosumab versus zoledronic acid in patients with bone metastases or MM showed that denosumab reduced SREs and delayed the appearance of the next SRE as efficiently as zoledronic acid (Henry et al. 2011). Results from the recently completed phase III trial showed that patients treated with zoledronic acid had a similar overall survival rate compared with denosumab-treated patients, that both were equally efficacious in preventing SREs, and that denosumab increases progression-free survival (Raje et al. 2016).

\section{Proteasome Antagonists}

Preclinical studies have shown that the proteasome inhibitor, bortezomib, and its analogs induce MM cell apoptosis and directly inhibit OC differentiation and bone resorption, increase osteoblastic bone formation, and prevent osteocyte apoptosis induced by MM cells (Accardi et al. 2015; Toscani et al. 2016). Retrospective analysis of multiple clinical trials showed that bortezomib and its derivatives increased alkaline phosphate levels and bone-formation markers in responding patients with relapsed MM compared with patients treated with dexamethasone (Zangari et al. 2005, 2011; Delforge et al. 2011; Eom et al. 2014). Although the exact mechanism of action of bortezomib on $\mathrm{OB}$ stimulation in $\mathrm{MM}$ patients has not been fully determined, recent studies reported that DKK1 serum levels and marker of bone resorption and RANKL were significantly decreased in patients that responded to bortezomib treatment (Terpos et al. 2006; Lund et al. 2010).

Several studies showed that patients treated with bortezomib showed signs of bone sclerosis around the lytic lesion, suggesting an initial process of bone healing that was not observed in patients treated with melphalan-prednisone only (Delforge et al. 2011). A histomorphometric study conducted by Giuliani and colleagues on bone marrow biopsies of MM patients showed a significant increase in the number of osteoblastic cells $/ \mathrm{mm}^{2}$ of bone tissue and Runx2-positive osteoblastic cells in MM patients responding to the bortezomib treatment (Giuliani et al. 2007a).

\section{CONCLUDING REMARKS}

The dramatic bone loss, severe bone pain, and pathological fractures that markedly decrease the quality of life of MM patients result from excessive osteoclastic bone resorption and a persistent decrease in osteoblastic bone formation. The lytic lesions that characterize MMBD do not heal even when the patients are in complete and prolonged remission, suggesting that bone repair is severely compromised and does not occur at previous sites of bone destruction. Increasing evidence suggests that by reducing tumor burden, chemotherapy could indirectly reduce the progression of MMBD. A clear understanding of the multiplicity of cellular and molecular mechanisms that regulate the interplay between bone marrow cells and MM cells, and the mechanisms responsible for osteoblastic suppression are needed for the development of new anabolic agents that in combination with the existing treatments can prevent further bone loss and potentially repair and restore bone damaged during the development of MMBD.

\section{COMPETING INTEREST STATEMENT}

G.D.R. is a consultant to Amgen and develops and presents continuing medical educational material for Clinical Care Options. S.M. has no conflict of interest regarding the publication of this paper.

\section{ACKNOWLEDGMENTS}

This work is supported by grants from Veterans Affairs (VA) Merit Review Grant 5101CX 000623-05 and National Institutes of Health (NIH) 5R01AR057308-09 (G.D.R.) and Multi- 
ple Myeloma Research Foundation NID 125752 (S.M.)

\section{REFERENCES}

Abbas S, Zhang YH, Clohisy JC, Abu-Amer Y. 2003. Tumor necrosis factor- $\alpha$ inhibits pre-osteoblast differentiation through its type-1 receptor. Cytokine 22: 33-41.

Abe M, Hiura K, Wilde J, Moriyama K, Hashimoto T, Ozaki S, Wakatsuki S, Kosaka M, Kido S, Inoue D, et al. 2002. Role for macrophage inflammatory protein (MIP)- $1 \alpha$ and MIP-1 $\beta$ in the development of osteolytic lesions in multiple myeloma. Blood 100: 2195-2202.

Abe M, Hiura K, Wilde J, Shioyasono A, Moriyama K, Hashimoto T, Kido S, Oshima T, Shibata H, Ozaki S, et al. 2004. Osteoclasts enhance myeloma cell growth and survival via cell-cell contact: A vicious cycle between bone destruction and myeloma expansion. Blood 104: 2484-2491.

Accardi F, Toscani D, Bolzoni M, Dalla Palma B, Aversa F, Giuliani N. 2015. Mechanism of action of bortezomib and the new proteasome inhibitors on myeloma cells and the bone microenvironment: Impact on myeloma-induced alterations of bone remodeling. Biomed Res Int 2015: 172458.

Adamik J, Jin S, Sun Q, Zhang P, Weiss KR, Anderson JL, Silbermann R, Roodman GD, Galson DL. 2017. EZH2 or HDAC1 inhibition reverses multiple myeloma-induced epigenetic suppression of osteoblast differentiation. $\mathrm{Mol}$ Cancer Res 15: 405-417.

Anderson DM, Maraskovsky E, Billingsley WL, Dougall WC, Tometsko ME, Roux ER, Teepe MC, DuBose RF, Cosman D, Galibert L. 1997. A homologue of the TNF receptor and its ligand enhance T-cell growth and dendritic-cell function. Nature 390: 175-179.

Annunziata CM, Davis RE, Demchenko Y, Bellamy W, Gabrea A, Zhan F, Lenz G, Hanamura I, Wright G, Xiao W, et al. 2007. Frequent engagement of the classical and alternative NF- $\mathrm{\kappa B}$ pathways by diverse genetic abnormalities in multiple myeloma. Cancer Cell 12: 115-130.

Bao H, Jiang M, Zhu M, Sheng F, Ruan J, Ruan C. 2009. Overexpression of annexin II affects the proliferation, apoptosis, invasion and production of proangiogenic factors in multiple myeloma. Int J Hematol 90: 177-185.

Baron R, Kneissel M. 2013. WNT signaling in bone homeostasis and disease: From human mutations to treatments Nat Med 19: 179-192.

Basu R, Hatton RD, Weaver CT. 2013. The Th17 family: Flexibility follows function. Immunol Rev 252: 89-103.

Bharti AC, Shishodia S, Reuben JM, Weber D, Alexanian R, Raj-Vadhan S, Estrov Z, Talpaz M, Aggarwal BB. 2004. Nuclear factor- $\kappa \mathrm{B}$ and STAT3 are constitutively active in $\mathrm{CD}_{138^{+}}$cells derived from multiple myeloma patients, and suppression of these transcription factors leads to apoptosis. Blood 103: 3175-3184.

Bhatnagar V, Wu Y, Goloubeva OG, Ruehle KT, Milliron TE, Harris CG, Rapoport AP, Yanovich S, Sausville EA, Baer $\mathrm{MR}$, et al. 2015. Disparities in black and white patients with multiple myeloma referred for autologous hematopoietic transplantation: A single center study. Cancer 121: 1064-1070.
Bolkun L, Lemancewicz D, Jablonska E, Kulczynska A, Bolkun-Skornicka U, Kloczko J, Dzieciol J. 2014. BAFF and APRIL as TNF superfamily molecules and angiogenesis parallel progression of human multiple myeloma. Ann Hematol 93: 635-644.

Bolzoni M, Donofrio G, Storti P, Guasco D, Toscani D, Lazzaretti M, Bonomini S, Agnelli L, Capocefalo A, Dalla Palma B, et al. 2013. Myeloma cells inhibit non-canonical wnt co-receptor ror2 expression in human bone marrow osteoprogenitor cells: Effect of wnt5a/ror2 pathway activation on the osteogenic differentiation impairment induced by myeloma cells. Leukemia 27: 451-463.

Botta C, Di Martino MT, Ciliberto D, Cuce M, Correale P, Rossi M, Tagliaferri P, Tassone P. 2016. A gene expression inflammatory signature specifically predicts multiple myeloma evolution and patients survival. Blood Cancer J 6: e511.

Boyce BF, Xing L. 2008. Functions of RANKL/RANK/OPG in bone modeling and remodeling. Arch Biochem Biophys 473: 139-146.

Boyce BF, Li P, Yao Z, Zhang Q, Badell IR, Schwarz EM, O'Keefe RJ, Xing L. 2005. TNF- $\alpha$ and pathologic bone resorption. Keio J Med 54: 127-131.

Boyle WJ, Simonet WS, Lacey DL. 2003. Osteoclast differentiation and activation. Nature 423: 337-342.

Brunetti G, Oranger A, Mori G, Centonze M, Colaianni G, Rizzi R, Liso V, Zallone A, Grano M, Colucci S. 2010. The formation of osteoclasts in multiple myeloma bone disease patients involves the secretion of soluble decoy receptor 3. Ann NY Acad Sci 1192: 298-302.

Brunetti G, Oranger A, Mori G, Specchia G, Rinaldi E, Curci P, Zallone A, Rizzi R, Grano M, Colucci S. 2011. Sclerostin is overexpressed by plasma cells from multiple myeloma patients. Ann NY Acad Sci 1237: 19-23.

Cackowski FC, Anderson JL, Patrene KD, Choksi RJ, Shapiro SD, Windle JJ, Blair HC, Roodman GD. 2010. Osteoclasts are important for bone angiogenesis. Blood 115: 140-149.

Cafforio P, Savonarola A, Stucci S, De Matteo M, Tucci M, Brunetti AE, Vecchio VM, Silvestris F. 2014. PTHrP produced by myeloma plasma cells regulates their survival and pro-osteoclast activity for bone disease progression. $J$ Bone Miner Res 29: 55-66.

Carson KR, Bates ML, Tomasson MH. 2014. The skinny on obesity and plasma cell myeloma: A review of the literature. Bone Marrow Transplant 49: 1009-1015.

Choi SJ, Cruz JC, Craig F, Chung H, Devlin RD, Roodman GD, Alsina M. 2000. Macrophage inflammatory protein $1-\alpha$ is a potential osteoclast stimulatory factor in multiple myeloma. Blood 96: 671-675.

Choi SJ, Oba Y, Gazitt Y, Alsina M, Cruz J, Anderson J, Roodman GD. 2001. Antisense inhibition of macrophage inflammatory protein 1- $\alpha$ blocks bone destruction in a model of myeloma bone disease. J Clin Invest 108: 18331841.

Colucci S, Brunetti G, Mori G, Oranger A, Centonze M, Mori C, Cantatore FP, Tamma R, Rizzi R, Liso V, et al. 2009. Soluble decoy receptor 3 modulates the survival and formation of osteoclasts from multiple myeloma bone disease patients. Leukemia 23: 2139-2146.

Colucci S, Brunetti G, Oranger A, Mori G, Sardone F, Specchia G, Rinaldi E, Curci P, Liso V, Passeri G, et al. 2011. 
Myeloma cells suppress osteoblasts through sclerostin secretion. Blood Cancer J 1: e27.

Cosman F, Crittenden DB, Adachi JD, Binkley N, Czerwinski E, Ferrari S, Hofbauer LC, Lau E, Lewiecki EM, Miyauchi A, et al. 2016. Romosozumab treatment in postmenopausal women with osteoporosis. N Engl J Med 375: 1532-1543.

Croucher PI, Shipman CM, Lippitt J, Perry M, Asosingh K, Hijzen A, Brabbs AC, van Beek EJ, Holen I, Skerry TM, et al. 2001. Osteoprotegerin inhibits the development of osteolytic bone disease in multiple myeloma. Blood 98: 3534-3540.

Dacquin R, Domenget C, Kumanogoh A, Kikutani H, Jurdic P, Machuca-Gayet I. 2011. Control of bone resorption by semaphorin $4 \mathrm{D}$ is dependent on ovarian function. PLoS ONE 6: e26627.

Dairaghi DJ, Oyajobi BO, Gupta A, McCluskey B, Miao S, Powers JP, Seitz LC, Wang Y, Zeng Y, Zhang P, et al. 2012. CCR1 blockade reduces tumor burden and osteolysis in vivo in a mouse model of myeloma bone disease. Blood 120: 1449-1457.

D'Amico L, Roato I. 2012. Cross-talk between T cells and osteoclasts in bone resorption. Bonekey Rep 1: 82.

Delforge M, Terpos E, Richardson PG, Shpilberg O, Khuageva NK, Schlag R, Dimopoulos MA, Kropff M, Spicka I, Petrucci MT, et al. 2011. Fewer bone disease events, improvement in bone remodeling, and evidence of bone healing with bortezomib plus melphalan-prednisone vs. melphalan-prednisone in the phase III VISTA trial in multiple myeloma. Eur J Haematol 86: 372-384.

Delgado-Calle J, Anderson J, Cregor MD, Hiasa M, Chirgwin JM, Carlesso N, Yoneda T, Mohammad KS, Plotkin LI, Roodman GD, et al. 2016. Bidirectional Notch signaling and osteocyte-derived factors in the bone marrow microenvironment promote tumor cell proliferation and bone destruction in multiple myeloma. Cancer Res 76: 1089-1100.

Delgado-Calle J, Anderson J, Cregor MD, Condon KW, Kuhstoss SA, Plotkin LI, Bellido T, Roodman GD 2017a. Genetic deletion of sost or pharmacological inhibition of sclerostin prevent multiple myeloma-induced bone disease without affecting tumor growth. Leukemia doi: 10.1038/leu.2017.152.

Delgado-Calle J, Sato AY, Bellido T. 2017b. Role and mechanism of action of sclerostin in bone. Bone 96: 29-37.

Dhodapkar KM, Barbuto S, Matthews P, Kukreja A, Mazumder A, Vesole D, Jagannath S, Dhodapkar MV. 2008. Dendritic cells mediate the induction of polyfunctional human IL17-producing cells (Th17-1 cells) enriched in the bone marrow of patients with myeloma. Blood 112: 2878-2885.

Dimopoulos K, Gimsing P, Gronbaek K. 2014. The role of epigenetics in the biology of multiple myeloma. Blood Cancer J 4: e207.

D'Souza S, del Prete D, Jin S, Sun Q, Huston AJ, Kostov FE, Sammut B, Hong CS, Anderson JL, Patrene KD, et al. 2011. Gfil expressed in bone marrow stromal cells is a novel osteoblast suppressor in patients with multiple myeloma bone disease. Blood 118: 6871-6880.

Eda H, Santo L, Wein MN, Hu DZ, Cirstea DD, Nemani N, Tai YT, Raines SE, Kuhstoss SA, Munshi NC, et al. 2016. Regulation of sclerostin expression in multiple myeloma by Dkk-1: A potential therapeutic strategy for myeloma bone disease. J Bone Miner Res 31: 1225-1234.

Ehrlich LA, Roodman GD. 2005. The role of immune cells and inflammatory cytokines in Paget's disease and multiple myeloma. Immunol Rev 208: 252-266.

Ehrlich LA, Chung HY, Ghobrial I, Choi SJ, Morandi F, Colla S, Rizzoli V, Roodman GD, Giuliani N. 2005. IL-3 is a potential inhibitor of osteoblast differentiation in multiple myeloma. Blood 106: 1407-1414.

Eom KS, Kim SJ, Lee JJ, Suh C, Kim JS, Yoon SS, Kim BS, Kang HJ, Choi YJ, Kim CS, et al. 2014. Changes in osteoblastic activity in patient who received bortezomib as second line treatment for plasma cell myeloma: A prospective multicenter study. Biomed Res Int 2014: 245247.

Foley J, Nickerson N, Riese DJ, Hollenhorst PC, Lorch G, Foley AM. 2012. At the crossroads: EGFR and PTHrP signaling in cancer-mediated diseases of bone. Odontology 100: 109-129.

Fowler JA, Lwin ST, Drake MT, Edwards JR, Kyle RA, Mundy GR, Edwards CM. 2011. Host-derived adiponectin is tumor-suppressive and a novel therapeutic target for multiple myeloma and the associated bone disease. Blood 118: $5872-5882$.

Frassanito MA, Cusmai A, Iodice G, Dammacco F. 2001. Autocrine interleukin-6 production and highly malignant multiple myeloma: Relation with resistance to drug-induced apoptosis. Blood 97: 483-489.

Fulciniti M, Tassone P, Hideshima T, Vallet S, Nanjappa P, Ettenberg SA, Shen Z, Patel N, Tai YT, Chauhan D, et al. 2009. Anti-DKK1 mAb (BHQ880) as a potential therapeutic agent for multiple myeloma. Blood 114: 371-379.

Garayoa M, Garcia JL, Santamaria C, Garcia-Gomez A, Blanco JF, Pandiella A, Hernandez JM, Sanchez-Guijo FM, del Canizo MC, Gutierrez NC, et al. 2009. Mesenchymal stem cells from multiple myeloma patients display distinct genomic profile as compared with those from normal donors. Leukemia 23: 1515-1527.

Gaur T, Lengner CJ, Hovhannisyan H, Bhat RA, Bodine PV, Komm BS, Javed A, van Wijnen AJ, Stein JL, Stein GS, et al. 2005. Canonical WNT signaling promotes osteogenesis by directly stimulating Runx2 gene expression. J Biol Chem 280: 33132-33140.

Ghali O, Chauveau C, Hardouin P, Broux O, Devedjian JC. 2010. TNF- $\alpha$ 's effects on proliferation and apoptosis in human mesenchymal stem cells depend on RUNX2 expression. J Bone Miner Res 25: 1616-1626.

Giuliani N, Bataille R, Mancini C, Lazzaretti M, Barille S 2001. Myeloma cells induce imbalance in the osteoprotegerin/osteoprotegerin ligand system in the human bone marrow environment. Blood 98: 3527-3533.

Giuliani N, Colla S, Rizzoli V. 2004. New insight in the mechanism of osteoclast activation and formation in multiple myeloma: Focus on the receptor activator of NF- $\mathrm{KB}$ ligand (RANKL). Exp Hematol 32: 685-691.

Giuliani N, Colla S, Morandi F, Lazzaretti M, Sala R, Bonomini S, Grano M, Colucci S, Svaldi M, Rizzoli V. 2005. Myeloma cells block RUNX2/CBFA1 activity in human bone marrow osteoblast progenitors and inhibit osteoblast formation and differentiation. Blood 106: 24722483. 
S. Marino and G.D. Roodman

Giuliani N, Rizzoli V, Roodman GD. 2006. Multiple myeloma bone disease: Pathophysiology of osteoblast inhibition. Blood 108: 3992-3996.

Giuliani N, Morandi F, Tagliaferri S, Lazzaretti M, Bonomini S, Crugnola M, Mancini C, Martella E, Ferrari L, Tabilio A, et al. 2007a. The proteasome inhibitor bortezomib affects osteoblast differentiation in vitro and in vivo in multiple myeloma patients. Blood 110: 334-338.

Giuliani N, Morandi F, Tagliaferri S, Lazzaretti M, Donofrio G, Bonomini S, Sala R, Mangoni M, Rizzoli V. 2007b. Production of Wnt inhibitors by myeloma cells: Potential effects on canonical Wnt pathway in the bone microenvironment. Cancer Res 67: 7665-7674.

Giuliani N, Storti P, Bolzoni M, Palma BD, Bonomini S. 2011. Angiogenesis and multiple myeloma. Cancer Microenviron 4: 325-337.

Giuliani N, Ferretti M, Bolzoni M, Storti P, Lazzaretti M, Dalla Palma B, Bonomini S, Martella E, Agnelli L, Neri $\mathrm{A}$, et al. 2012. Increased osteocyte death in multiple myeloma patients: Role in myeloma-induced osteoclast formation. Leukemia 26: 1391-1401.

Gladue RP, Brown MF, Zwillich SH. 2010. CCR1 antagonists: What have we learned from clinical trials. Curr Top Med Chem 10: 1268-1277.

Glass DA 2nd, Bialek P, Ahn JD, Starbuck M, Patel MS, Clevers H, Taketo MM, Long F, McMahon AP, Lang RA, et al. 2005. Canonical Wnt signaling in differentiated osteoblasts controls osteoclast differentiation. Dev Cell 8: 751-764.

Guise TA, Yin JJ, Taylor SD, Kumagai Y, Dallas M, Boyce BF, Yoneda T, Mundy GR. 1996. Evidence for a causal role of parathyroid hormone-related protein in the pathogenesis of human breast cancer-mediated osteolysis. J Clin Invest 98: 1544-1549.

Gunn WG, Conley A, Deininger L, Olson SD, Prockop DJ, Gregory CA. 2006. A crosstalk between myeloma cells and marrow stromal cells stimulates production of DKK1 and interleukin-6: A potential role in the development of lytic bone disease and tumor progression in multiple myeloma. Stem Cells 24: 986-991.

Han JH, Choi SJ, Kurihara N, Koide M, Oba Y, Roodman GD. 2001. Macrophage inflammatory protein-1 $\alpha$ is an osteoclastogenic factor in myeloma that is independent of receptor activator of nuclear factor $\mathrm{\kappa B}$ ligand. Blood 97 : 3349-3353.

He J, Liu Z, Zheng Y, Qian J, Li H, Lu Y, Xu J, Hong B, Zhang M, Lin P, et al. 2012. p38 MAPK in myeloma cells regulates osteoclast and osteoblast activity and induces bone destruction. Cancer Res 72: 6393-6402.

Healy CF, Murray JG, Eustace SJ, Madewell J, O'Gorman PJ, O'Sullivan P. 2011. Multiple myeloma: A review of imaging features and radiological techniques. Bone Marrow Res 2011: 583439.

Heider U, Langelotz C, Jakob C, Zavrski I, Fleissner C, Eucker J, Possinger K, Hofbauer LC, Sezer O. 2003. Expression of receptor activator of nuclear factor $\kappa \mathrm{B}$ ligand on bone marrow plasma cells correlates with osteolytic bone disease in patients with multiple myeloma. Clin Cancer Res 9: 1436-1440.

Henry DH, Costa L, Goldwasser F, Hirsh V, Hungria V, Prausova J, Scagliotti GV, Sleeboom H, Spencer A, Vadhan-Raj S, et al. 2011. Randomized, double-blind study of denosumab versus zoledronic acid in the treatment of bone metastases in patients with advanced cancer (excluding breast and prostate cancer) or multiple myeloma. J Clin Oncol 29: 1125-1132.

Hiasa M, Okui T, Allette YM, Ripsch MS, Sun-Wada GH, Wakabayashi H, Roodman GD, White FA, Yoneda T. 2017. Bone pain induced by multiple myeloma is reduced by targeting V-ATPase and ASIC3. Cancer Res 77: 1283 1295.

Hideshima T, Akiyama M, Hayashi T, Richardson P, Schlossman R, Chauhan D, Anderson KC. 2003. Targeting p38 MAPK inhibits multiple myeloma cell growth in the bone marrow milieu. Blood 101: 703-705.

Hiruma Y, Kurihara N, Subler MA, Zhou H, Boykin CS, Zhang H, Ishizuka S, Dempster DW, Roodman GD, Windle JJ. 2008. A SQSTM1/p62 mutation linked to Paget's disease increases the osteoclastogenic potential of the bone microenvironment. Hum Mol Genet 17: 3708-3719.

Hiruma Y, Honjo T, Jelinek DF, Windle JJ, Shin J, Roodman GD, Kurihara N. 2009. Increased signaling through p62 in the marrow microenvironment increases myeloma cell growth and osteoclast formation. Blood 113: 4894-4902.

Hofbauer LC, Heufelder AE. 2001. Role of receptor activator of nuclear factor- $\mathrm{\kappa B}$ ligand and osteoprotegerin in bone cell biology. J Mol Med 79: 243-253.

Hofbauer LC, Lacey DL, Dunstan CR, Spelsberg TC, Riggs BL, Khosla S. 1999. Interleukin-1 $\beta$ and tumor necrosis factor- $\alpha$, but not interleukin- 6 , stimulate osteoprotegerin ligand gene expression in human osteoblastic cells. Bone 25: $255-259$.

Hofmann JN, Liao LM, Pollak MN, Wang Y, Pfeiffer RM, Baris D, Andreotti G, Lan Q, Landgren O, Rothman N, et al. 2012. A prospective study of circulating adipokine levels and risk of multiple myeloma. Blood 120: 4418-4420.

Howlader N, Noone AM, Krapcho M, Miller D, Bishop K, Altekruse SF, Kosary CL, Yu M, Ruhl J, Tatalovich Z, Mariotto A, et al. 2016. SEER Cancer Statistics Review, 1975-2013. National Cancer Institute, Bethesda, MD.

Hsu H, Lacey DL, Dunstan CR, Solovyev I, Colombero A, Timms E, Tan HL, Elliott G, Kelley MJ, Sarosi I, et al. 1999. Tumor necrosis factor receptor family member RANK mediates osteoclast differentiation and activation induced by osteoprotegerin ligand. Proc Natl Acad Sci 96: 3540-3545.

Ikeda T, Kasai M, Utsuyama M, Hirokawa K. 2001. Determination of three isoforms of the receptor activator of nuclear factor- $\mathrm{\kappa B}$ ligand and their differential expression in bone and thymus. Endocrinology 142: 1419-1426.

Issa ME, Takhsha FS, Chirumamilla CS, Perez-Novo C, Vanden Berghe W, Cuendet M. 2017. Epigenetic strategies to reverse drug resistance in heterogeneous multiple myeloma. Clin Epigenetics 9: 17.

Iyer SP, Beck JT, Stewart AK, Shah J, Kelly KR, Isaacs R, Bilic S, Sen S, Munshi NC. 2014. A phase IB multicentre dosedetermination study of BHQ880 in combination with anti-myeloma therapy and zoledronic acid in patients with relapsed or refractory multiple myeloma and prior skeletal-related events. Br J Haematol 167: 366-375.

Johrer K, Janke K, Krugmann J, Fiegl M, Greil R. 2004. Transendothelial migration of myeloma cells is increased by tumor necrosis factor (TNF)- $\alpha$ via TNF receptor 2 and 
autocrine up-regulation of MCP-1. Clin Cancer Res 10: 1901-1910.

Kaiser M, Mieth M, Liebisch P, Oberlander R, Rademacher J, Jakob C, Kleeberg L, Fleissner C, Braendle E, Peters M, et al. 2008. Serum concentrations of DKK-1 correlate with the extent of bone disease in patients with multiple myeloma. Eur J Haematol 80: 490-494.

Karaplis AC, Goltzman D. 2000. PTH and PTHrP effects on the skeleton. Rev Endocr Metab Disord 1: 331-341.

Kassen D, Moore S, Percy L, Herledan G, Bounds D, Rodriguez-Justo M, Croucher P, Yong K. 2014. The bone marrow stromal compartment in multiple myeloma patients retains capability for osteogenic differentiation in vitro: Defining the stromal defect in myeloma. Br J Haematol 167: 194-206.

Katz BZ. 2010. Adhesion molecules-The lifelines of multiple myeloma cells. Semin Cancer Biol 20: 186-195.

Kitazawa R, Kitazawa S, Kajimoto K, Sowa H, Sugimoto T, Matsui T, Chihara K, Maeda S. 2002. Expression of parathyroid hormone-related protein (PTHrP) in multiple myeloma. Pathol Int 52: 63-68.

Kramer I, Halleux C, Keller H, Pegurri M, Gooi JH, Weber PB, Feng JQ, Bonewald LF, Kneissel M. 2010. Osteocyte $\mathrm{Wnt} / \beta$-catenin signaling is required for normal bone homeostasis. Mol Cell Biol 30: 3071-3085.

Kremer R, Li J, Camirand A, Karaplis AC. 2011. Parathyroid hormone related protein (PTHrP) in tumor progression. Adv Exp Med Biol 720: 145-160.

Kumar S, Witzig TE, Timm M, Haug J, Wellik L, Fonseca R, Greipp PR, Rajkumar SV. 2003. Expression of VEGF and its receptors by myeloma cells. Leukemia 17: 2025-2031.

Kumar S, Witzig TE, Dispenzieri A, Lacy MQ, Wellik LE Fonseca R, Lust JA, Gertz MA, Kyle RA, Greipp PR, et al. 2004. Effect of thalidomide therapy on bone marrow angiogenesis in multiple myeloma. Leukemia 18: 624-627.

Kumar AK, Dakhil C, Teeka Satyan M, Haideri N. 2014. Extramedullary progression of multiple myeloma despite concomitant medullary response to multiple combination therapies and autologous transplant: A case report. J Med Case Rep 8: 299.

Kurihara N, Hiruma Y, Zhou H, Subler MA, Dempster DW, Singer FR, Reddy SV, Gruber HE, Windle JJ, Roodman GD. 2007. Mutation of the sequestosome 1 (p62) gene increases osteoclastogenesis but does not induce Paget disease. J Clin Invest 117: 133-142.

Kyle RA, Rajkumar SV. 2004. Multiple myeloma. N Engl J Med 351: 1860-1873.

Kyle RA, Rajkumar SV. 2008. Multiple myeloma. Blood 111: 2962-2972.

Kyle RA, Yee GC, Somerfield MR, Flynn PJ, Halabi S, Jagannath S, Orlowski RZ, Roodman DG, Twilde P, Anderson $\mathrm{K}$, et al. 2007. American Society of Clinical Oncology 2007 clinical practice guideline update on the role of bisphosphonates in multiple myeloma. J Clin Oncol 25: 2464-2472.

Lacey DL, Timms E, Tan HL, Kelley MJ, Dunstan CR, Burgess T, Elliott R, Colombero A, Elliott G, Scully S, et al 1998. Osteoprotegerin ligand is a cytokine that regulates osteoclast differentiation and activation. Cell 93: 165-176.

Lee JW, Chung HY, Ehrlich LA, Jelinek DF, Callander NS, Roodman GD, Choi SJ. 2004. IL-3 expression by myeloma cells increases both osteoclast formation and growth of myeloma cells. Blood 103: 2308-2315.

Lentzsch S, Gries M, Janz M, Bargou R, Dorken B, Mapara MY. 2003. Macrophage inflammatory protein 1- $\alpha$ (MIP$1 \alpha)$ triggers migration and signaling cascades mediating survival and proliferation in multiple myeloma (MM) cells. Blood 101: 3568-3573.

Li B, Shi M, Li J, Zhang H, Chen B, Chen L, Gao W, Giuliani N, Zhao RC. 2007. Elevated tumor necrosis factor- $\alpha$ suppresses TAZ expression and impairs osteogenic potential of Flk- $1^{+}$mesenchymal stem cells in patients with multiple myeloma. Stem Cells Dev 16: 921-930.

Li ZW, Chen H, Campbell RA, Bonavida B, Berenson JR. 2008. NF- $\mathrm{KB}$ in the pathogenesis and treatment of multiple myeloma. Curr Opin Hematol 15: 391-399.

Li J, Karaplis AC, Huang DC, Siegel PM, Camirand A, Yang XF, Muller WJ, Kremer R. 2011. PTHrP drives breast tumor initiation, progression, and metastasis in mice and is a potential therapy target. J Clin Invest 121: $4655-4669$.

Liao J, McCauley LK. 2006. Skeletal metastasis: Established and emerging roles of parathyroid hormone related protein (PTHrP). Cancer Metastasis Rev 25: 559-571.

Lippai M, Low P. 2014. The role of the selective adaptor p62 and ubiquitin-like proteins in autophagy. Biomed Res Int 2014: 832704.

Liu Z, Xu J, He J, Liu H, Lin P, Wan X, Navone NM, Tong Q, Kwak LW, Orlowski RZ, et al. 2015. Mature adipocytes in bone marrow protect myeloma cells against chemotherapy through autophagy activation. Oncotarget 6: 3432934341.

Lopez-Corral L, Corchete LA, Sarasquete ME, Mateos MV, Garcia-Sanz R, Ferminan E, Lahuerta JJ, Blade J, Oriol A, Teruel AI, et al. 2014. Transcriptome analysis reveals molecular profiles associated with evolving steps of monoclonal gammopathies. Haematologica 99: 1365-1372.

Lorenzo J, Horowitz M, Choi Y. 2008. Osteoimmunology: Interactions of the bone and immune system. Endocr Rev 29: 403-440.

Lotinun S, Pearsall RS, Davies MV, Marvell TH, Monnell TE, Ucran J, Fajardo RJ, Kumar R, Underwood KW, Seehra J, et al. 2010. A soluble activin receptor type IIA fusion protein (ACE-011) increases bone mass via a dual anabolic-antiresorptive effect in Cynomolgus monkeys. Bone 46: $1082-1088$.

Lund T, Soe K, Abildgaard N, Garnero P, Pedersen PT, Ormstrup T, Delaisse JM, Plesner T. 2010. First-line treatment with bortezomib rapidly stimulates both osteoblast activity and bone matrix deposition in patients with multiple myeloma, and stimulates osteoblast proliferation and differentiation in vitro. Eur J Haematol 85: 290-299.

Magrangeas F, Nasser V, Avet-Loiseau H, Loriod B, Decaux O, Granjeaud S, Bertucci F, Birnbaum D, Nguyen C, Harousseau JL, et al. 2003. Gene expression profiling of multiple myeloma reveals molecular portraits in relation to the pathogenesis of the disease. Blood 101: 4998-5006.

Mahtouk K, Moreaux J, Hose D, Reme T, Meissner T, Jourdan M, Rossi JF, Pals ST, Goldschmidt H, Klein B. 2010. Growth factors in multiple myeloma: A comprehensive analysis of their expression in tumor cells and bone marrow environment using Affymetrix microarrays. $B M C$ Cancer 10: 198. 
McDonald MM, Reagan MR, Youlten SE, Mohanty ST, Seckinger A, Terry RL, Pettitt JA, Simic MK, Cheng TL, Morse A, et al. 2017. Inhibiting the osteocyte specific protein sclerostin increases bone mass and fracture resistance in multiple myeloma. Blood 129: 3452-3464.

Medina EA, Oberheu K, Polusani SR, Ortega V, Velagaleti GV, Oyajobi BO. 2014. PKA/AMPK signaling in relation to adiponectin's antiproliferative effect on multiple myeloma cells. Leukemia 28: 2080-2089.

Melton LJ III, Kyle RA, Achenbach SJ, Oberg AL, Rajkumar SV. 2005. Fracture risk with multiple myeloma: A population-based study. J Bone Miner Res 20: 487-493.

Menu E, De Leenheer E, De Raeve H, Coulton L, Imanishi T, Miyashita K, Van Valckenborgh E, Van Riet I, Van Camp B, Horuk R, et al. 2006. Role of CCR1 and CCR5 in homing and growth of multiple myeloma and in the development of osteolytic lesions: A study in the 5TMM model. Clin Exp Metastasis 23: 291-300.

Milan E, Perini T, Resnati M, Orfanelli U, Oliva L, Raimondi A, Cascio P, Bachi A, Marcatti M, Ciceri F, et al. 2015. A plastic SQSTM1/p62-dependent autophagic reserve maintains proteostasis and determines proteasome inhibitor susceptibility in multiple myeloma cells. Autophagy 11: 1161-1178.

Mitsiades N, Mitsiades CS, Poulaki V, Chauhan D, Richardson PG, Hideshima T, Munshi N, Treon SP, Anderson KC. 2002. Biologic sequelae of nuclear factor- $\mathrm{\kappa B}$ blockade in multiple myeloma: Therapeutic applications. Blood 99: 4079-4086.

Molloy S, Lai M, Pratt G, Ramasamy K, Wilson D, Quraishi N, Auger M, Cumming D, Punekar M, Quinn M, et al. 2015. Optimizing the management of patients with spinal myeloma disease. Br J Haematol 171: 332-343.

Mori Y, Shimizu N, Dallas M, Niewolna M, Story B, Williams PJ, Mundy GR, Yoneda T. 2004. Anti- $\alpha 4$ integrin antibody suppresses the development of multiple myeloma and associated osteoclastic osteolysis. Blood 104: 2149-2154.

Moscat J, Diaz-Meco MT, Wooten MW. 2007. Signal integration and diversification through the p62 scaffold protein. Trends Biochem Sci 32: 95-100.

Mundy GR. 2002. Metastasis to bone: Causes, consequences and therapeutic opportunities. Nat Rev Cancer 2: 584593.

Murray TM, Rao LG, Divieti P, Bringhurst FR. 2005. Parathyroid hormone secretion and action: Evidence for discrete receptors for the carboxyl-terminal region and related biological actions of carboxyl-terminal ligands. Endocr Rev 26: 78-113.

Nakagawa N, Kinosaki M, Yamaguchi K, Shima N, Yasuda H, Yano K, Morinaga T, Higashio K. 1998. RANK is the essential signaling receptor for osteoclast differentiation factor in osteoclastogenesis. Biochem Biophys Res Commun 253: 395-400.

Nakashima T, Hayashi M, Fukunaga T, Kurata K, Oh-Hora M, Feng JQ, Bonewald LF, Kodama T, Wutz A, Wagner $\mathrm{EF}$, et al. 2011. Evidence for osteocyte regulation of bone homeostasis through RANKL expression. Nat Med 17: 1231-1234.

Nanes MS. 2003. Tumor necrosis factor- $\alpha$ : Molecular and cellular mechanisms in skeletal pathology. Gene 321: 115 .
Negishi-Koga T, Shinohara M, Komatsu N, Bito H, Kodama T, Friedel RH, Takayanagi H. 2011. Suppression of bone formation by osteoclastic expression of semaphorin $4 \mathrm{D}$. Nat Med 17: 1473-1480.

Noonan K, Marchionni L, Anderson J, Pardoll D, Roodman GD, Borrello I. 2010. A novel role of IL-17-producing lymphocytes in mediating lytic bone disease in multiple myeloma. Blood 116: 3554-3563.

Oba Y, Lee JW, Ehrlich LA, Chung HY, Jelinek DF, Callander NS, Horuk R, Choi SJ, Roodman GD. 2005. MIP- $1 \alpha$ utilizes both CCR1 and CCR5 to induce osteoclast formation and increase adhesion of myeloma cells to marrow stromal cells. Exp Hematol 33: 272-278.

Oyajobi BO, Franchin G, Williams PJ, Pulkrabek D, Gupta A, Munoz S, Grubbs B, Zhao M, Chen D, Sherry B, et al. 2003. Dual effects of macrophage inflammatory protein$1 \alpha$ on osteolysis and tumor burden in the murine 5TGM1 model of myeloma bone disease. Blood 102: 311-319.

Paget S. 1889. The distribution of secondary growths in cancer of the breast. Cancer Metastasis Rev 8: 98-101.

Patnaik A, Weiss GJ, Leonard JE, Rasco DW, Sachdev JC, Fisher TL, Winter LA, Reilly C, Parker RB, Mutz D, et al. 2016. Safety, pharmacokinetics, and pharmacodynamics of a humanized anti-semaphorin $4 \mathrm{D}$ antibody, in a firstin-human study of patients with advanced solid tumors. Clin Cancer Res 22: 827-836.

Pearsall RS, Canalis E, Cornwall-Brady M, Underwood KW, Haigis B, Ucran J, Kumar R, Pobre E, Grinberg A, Werner ED, et al. 2008. A soluble activin type IIA receptor induces bone formation and improves skeletal integrity. Proc Natl Acad Sci 105: 7082-7087.

Pearse RN, Sordillo EM, Yaccoby S, Wong BR, Liau DF, Colman N, Michaeli J, Epstein J, Choi Y. 2001. Multiple myeloma disrupts the TRANCE/ osteoprotegerin cytokine axis to trigger bone destruction and promote tumor progression. Proc Natl Acad Sci 98: 11581-11586.

Plotkin LI, Gortazar AR, Davis HM, Condon KW, Gabilondo H, Maycas M, Allen MR, Bellido T. 2015. Inhibition of osteocyte apoptosis prevents the increase in osteocytic receptor activator of nuclear factor $\kappa \mathrm{B}$ ligand (RANKL) but does not stop bone resorption or the loss of bone induced by unloading. J Biol Chem 290: 18934-18942.

Pozzi S, Raje N. 2011. The role of bisphosphonates in multiple myeloma: Mechanisms, side effects, and the future. Oncologist 16: 651-662.

Prabhala RH, Pelluru D, Fulciniti M, Prabhala HK, Nanjappa P, Song W, Pai C, Amin S, Tai YT, Richardson PG, et al. 2010. Elevated IL-17 produced by $\mathrm{T}_{\mathrm{H}} 17$ cells promotes myeloma cell growth and inhibits immune function in multiple myeloma. Blood 115: 5385-5392.

Pruneri G, Ponzoni M, Ferreri AJ, Decarli N, Tresoldi M, Raggi F, Baldessari C, Freschi M, Baldini L, Goldaniga M, et al. 2002. Microvessel density, a surrogate marker of angiogenesis, is significantly related to survival in multiple myeloma patients. Br J Haematol 118: 817-820.

Raje N, Vadhan-Raj S, Willenbacher W, Terpos E, Hungria V, Spencer A, Alexeeva Y, Facon T, Stewart AK, Feng A, et al. 2016. Evaluating results from the multiple myeloma patient subset treated with denosumab or zoledronic acid in a randomized phase 3 trial. Blood Cancer J 6: e378.

Raje N, Terpos E, Willenbacher W, Shimizu K, Garcia-Sanz R, Durie BG, Legiec W, Krejci M, Laribi K, Zhu L, et al. 
2017. An international, randomized, double blind trial comparing denosumab with zoledronic acid (ZA) for the treatment of bone disease in patients (pts) with newly diagnosed multiple myeloma. Clin Lymphoma Myeloma Leuk 17: e27-e28.

Rajkumar SV, Mesa RA, Fonseca R, Schroeder G, Plevak MF, Dispenzieri A, Lacy MQ, Lust JA, Witzig TE, Gertz MA, et al. 2002. Bone marrow angiogenesis in 400 patients with monoclonal gammopathy of undetermined significance, multiple myeloma, and primary amyloidosis. Clin Cancer Res 8: 2210-2216.

Rampa C, Tian E, Vatsveen TK, Buene G, Slordahl TS, Borset M, Waage A, Sundan A. 2014. Identification of the source of elevated hepatocyte growth factor levels in multiple myeloma patients. Biomark Res 2: 8 .

Roccaro AM, Sacco A, Maiso P, Azab AK, Tai YT, Reagan M, Azab F, Flores LM, Campigotto F, Weller E, et al. 2013. BM mesenchymal stromal cell-derived exosomes facilitate multiple myeloma progression. J Clin Invest 123: 1542-1555.

Roodman GD. 1999. Cell biology of the osteoclast. Exp Hematol 27: 1229-1241.

Roodman GD. 2002. Role of the bone marrow microenvironment in multiple myeloma. J Bone Miner Res 17: 1921-1925.

Roodman GD. 2004. Mechanisms of bone metastasis. NEngl J Med 350: 1655-1664.

Roodman GD. 2008. Skeletal imaging and management of bone disease. Hematol Am Soc Hematol Educ Program 2008: 313-319.

Roodman GD. 2009. Pathogenesis of myeloma bone disease. Leukemia 23: 435-441.

Roodman GD. 2010. Pathogenesis of myeloma bone disease. J Cell Biochem 109: 283-291.

Roodman GD. 2011. Osteoblast function in myeloma. Bone 48: $135-140$.

Roodman GD, Dougall WC. 2008. RANK ligand as a therapeutic target for bone metastases and multiple myeloma. Cancer Treat Rev 34: 92-101.

Rosen CJ. 2013. Primer on the metabolic bone diseases and disorders of mineral metabolism. Wiley-Blackwell, Ames, IA.

Roy P, Mukherjee T, Chatterjee B, Vijayaragavan B, Banoth B, Basak S. 2017. Non-canonical NFkB mutations reinforce pro-survival TNF response in multiple myeloma through an autoregulatory RelB:p50 NF- $\mathrm{\kappa B}$ pathway. Oncogene 36: 1417-1429.

Saad F, Lipton A, Cook R, Chen YM, Smith M, Coleman R. 2007. Pathologic fractures correlate with reduced survival in patients with malignant bone disease. Cancer 110: 1860-1867.

Schmiedel BJ, Scheible CA, Nuebling T, Kopp HG, Wirths S, Azuma M, Schneider P, Jung G, Grosse-Hovest L, Salih HR. 2013. RANKL expression, function, and therapeutic targeting in multiple myeloma and chronic lymphocytic leukemia. Cancer Res 73: 683-694.

Sezer O, Heider U, Jakob C, Eucker J, Possinger K. 2002a. Human bone marrow myeloma cells express RANKL. $J$ Clin Oncol 20: 353-354.

Sezer O, Heider U, Jakob C, Zavrski I, Eucker J, Possinger K, Sers C, Krenn V. 2002b. Immunocytochemistry reveals
RANKL expression of myeloma cells. Blood 99: 46464647; author reply 4647.

Siegel RL, Miller KD, Jemal A. 2017. Cancer statistics, 2017. CA Cancer J Clin 67: 7-30.

Silbermann R, Bolzoni M, Storti P, Guasco D, Bonomini S, Zhou D, Wu J, Anderson JL, Windle JJ, Aversa F, et al. 2014. Bone marrow monocyte-/macrophage-derived activin A mediates the osteoclastogenic effect of IL-3 in multiple myeloma. Leukemia 28: 951-954.

Silbermann R, Adamik J, Zhou D, Xie XQ, Kurihara N, Roodman GD, Galson DL. 2016. p62-ZZ domain signaling inhibition rescues MM-induced epigenetic repression at the Runx2 promoter and allows osteoblast differentiation of MM patient pre-osteoblasts in vitro. Blood 128: 4410.

Silvestris F, Cafforio P, Calvani N, Dammacco F. 2004. Impaired osteoblastogenesis in myeloma bone disease: Role of upregulated apoptosis by cytokines and malignant plasma cells. Br J Haematol 126: 475-486.

Silvestris F, Cafforio P, De Matteo M, Calvani N, Frassanito MA, Dammacco F. 2008. Negative regulation of the osteoblast function in multiple myeloma through the repressor gene E4BP4 activated by malignant plasma cells. Clin Cancer Res 14: 6081-6091.

Simonet WS, Lacey DL, Dunstan CR, Kelley M, Chang MS, Luthy R, Nguyen HQ, Wooden S, Bennett L, Boone T, et al. 1997. Osteoprotegerin: A novel secreted protein involved in the regulation of bone density. Cell 89: 309-319.

Soki FN, Park SI, McCauley LK. 2012. The multifaceted actions of PTHrP in skeletal metastasis. Future Oncol 8: 803-817.

Spencer GJ, Utting JC, Etheridge SL, Arnett TR, Genever PG. 2006. Wnt signalling in osteoblasts regulates expression of the receptor activator of NF- $\mathrm{KB}$ ligand and inhibits osteoclastogenesis in vitro. J Cell Sci 119: 1283-1296.

Sternlicht H, Glezerman IG. 2015. Hypercalcemia of malignancy and new treatment options. Ther Clin Risk Manag 11: 1779-1788.

Suvannasankha A, Crean CD, Tompkins DR, Delgado-Calle J, Bellido TM, Roodman GD, Chirgwin JM. 2016. Regulation of osteoblast function in myeloma bone disease by semaphorin 4D. Blood 128: 4439.

Takada I, Mihara M, Suzawa M, Ohtake F, Kobayashi S, Igarashi M, Youn MY, Takeyama K, Nakamura T, Mezaki Y, et al. 2007. A histone lysine methyltransferase activated by non-canonical Wnt signalling suppresses PPAR- $\gamma$ transactivation. Nat Cell Biol 9: 1273-1285.

Takahashi N, Udagawa N, Suda T. 2014. Vitamin D endocrine system and osteoclasts. Bonekey Rep 3: 495.

Tanaka Y, Abe M, Hiasa M, Oda A, Amou H, Nakano A, Takeuchi K, Kitazoe K, Kido S, Inoue D, et al. 2007. Myeloma cell-osteoclast interaction enhances angiogenesis together with bone resorption: A role for vascular endothelial cell growth factor and osteopontin. Clin Cancer Res 13: 816-823.

Teramachi J, Silbermann R, Yang P, Zhao W, Mohammad KS, Guo J, Anderson JL, Zhou D, Feng R, Myint KZ, et al. 2016. Blocking the $\mathrm{ZZ}$ domain of sequestosome1/p62 suppresses myeloma growth and osteoclast formation in vitro and induces dramatic bone formation in myelomabearing bones in vivo. Leukemia 30: 390-398. 
Terpos E, Szydlo R, Apperley JF, Hatjiharissi E, Politou M Meletis J, Viniou N, Yataganas X, Goldman JM, Rahemtulla A. 2003. Soluble receptor activator of nuclear factor $\kappa \mathrm{B}$ ligand-osteoprotegerin ratio predicts survival in multiple myeloma: Proposal for a novel prognostic index. Blood 102: 1064-1069.

Terpos E, Heath DJ, Rahemtulla A, Zervas K, Chantry A Anagnostopoulos A, Pouli A, Katodritou E, Verrou E, Vervessou EC, et al. 2006. Bortezomib reduces serum dickkopf-1 and receptor activator of nuclear factor- $\mathrm{\kappa B}$ ligand concentrations and normalises indices of bone remodelling in patients with relapsed multiple myeloma. $\mathrm{Br}$ J Haematol 135: 688-692.

Terpos E, Sezer O, Croucher PI, Garcia-Sanz R, Boccadoro M, San Miguel J, Ashcroft J, Blade J, Cavo M, Delforge M, et al. 2009. The use of bisphosphonates in multiple myeloma: Recommendations of an expert panel on behalf of the European Myeloma Network. Ann Oncol 20: 13031317.

Terpos E, Christoulas D, Katodritou E, Bratengeier C, Gkotzamanidou M, Michalis E, Delimpasi S, Pouli A, Meletis J, Kastritis E, et al. 2012a. Elevated circulating sclerostin correlates with advanced disease features and abnormal bone remodeling in symptomatic myeloma: Reduction post-bortezomib monotherapy. Int J Cancer 131: 14661471.

Terpos E, Kastritis E, Bagratuni T, Christoulas D, Papatheodorou A, Kanellias N, Gkotzamanidou M, EleutherakisPapaiakovou E, Gavriatopoulou M, Dimopoulos MA 2012b. Semaphorin-4D and plexin-B1 are elevated in multiple myeloma microenvironment and possibly contribute in the development of lytic bone disease. Blood 120: 1819.

Tian E, Zhan F, Walker R, Rasmussen E, Ma Y, Barlogie B, Shaughnessy JD Jr. 2003. The role of the Wnt-signaling antagonist DKK1 in the development of osteolytic lesions in multiple myeloma. N Engl J Med 349: 2483-2494.

Toraldo G, Roggia C, Qian WP, Pacifici R, Weitzmann MN 2003. IL-7 induces bone loss in vivo by induction of receptor activator of nuclear factor $\kappa \mathrm{B}$ ligand and tumor necrosis factor $\alpha$ from T cells. Proc Natl Acad Sci 100: 125-130.

Tornatore L, Sandomenico A, Raimondo D, Low C, Rocci A, Tralau-Stewart C, Capece D, D’Andrea D, Bua M, Boyle $\mathrm{E}$, et al. 2014. Cancer-selective targeting of the NF- $\mathrm{\kappa B}$ survival pathway with GADD45/MKK7 inhibitors. Cancer Cell 26: 495-508.

Toscani D, Palumbo C, Dalla Palma B, Ferretti M, Bolzoni M, Marchica V, Sena P, Martella E, Mancini C, Ferri V, et al. 2016. The proteasome inhibitor bortezomib maintains osteocyte viability in multiple myeloma patients by reducing both apoptosis and autophagy: A new function for proteasome inhibitors. J Bone Miner Res 31: 815-827.

Tsubaki M, Kato C, Isono A, Kaneko J, Isozaki M, Satou T, Itoh T, Kidera Y, Tanimori Y, Yanae M, et al. 2010. Macrophage inflammatory protein- $1 \alpha$ induces osteoclast formation by activation of the MEK/ERK/c-Fos pathway and inhibition of the p38MAPK/IRF-3/IFN- $\beta$ pathway. J Cell Biochem 111: 1661-1672.

Uneda S, Hata H, Matsuno F, Harada N, Mitsuya Y, Kawano F, Mitsuya H. 2003. Macrophage inflammatory protein$1 \alpha$ is produced by human multiple myeloma (MM) cells and its expression correlates with bone lesions in patients with MM. Br J Haematol 120: 53-55.

Vallet S, Raje N, Ishitsuka K, Hideshima T, Podar K, Chhetri S, Pozzi S, Breitkreutz I, Kiziltepe T, Yasui H, et al. 2007. MLN3897, a novel CCR1 inhibitor, impairs osteoclastogenesis and inhibits the interaction of multiple myeloma cells and osteoclasts. Blood 110: 3744-3752.

Vallet S, Mukherjee S, Vaghela N, Hideshima T, Fulciniti M, Pozzi S, Santo L, Cirstea D, Patel K, Sohani AR, et al. 2010. Activin A promotes multiple myeloma-induced osteolysis and is a promising target for myeloma bone disease. Proc Natl Acad Sci 107: 5124-5129.

Vallet S, Pozzi S, Patel K, Vaghela N, Fulciniti MT, Veiby P, Hideshima T, Santo L, Cirstea D, Scadden DT, et al. 2011. A novel role for CCL3 (MIP-1 $\alpha$ ) in myeloma-induced bone disease via osteocalcin downregulation and inhibition of osteoblast function. Leukemia 25: 11741181.

van Bezooijen RL, ten Dijke P, Papapoulos SE, Lowik CW. 2005. SOST/sclerostin, an osteocyte-derived negative regulator of bone formation. Cytokine Growth Factor Rev 16: 319-327.

Van den Wyngaert T, Huizing MT, Vermorken JB. 2007. Osteonecrosis of the jaw related to the use of bisphosphonates. Curr Opin Oncol 19: 315-322.

Vanderkerken K, Medicherla S, Coulton L, De Raeve H, Willems A, Lawson M, Van Camp B, Protter AA, Higgins LS, Menu E, et al. 2007. Inhibition of p38 $\alpha$ mitogen-activated protein kinase prevents the development of osteolytic bone disease, reduces tumor burden, and increases survival in murine models of multiple myeloma. Cancer Res 67: 4572-4577.

Wada T, Nakashima T, Hiroshi N, Penninger JM. 2006 RANKL-RANK signaling in osteoclastogenesis and bone disease. Trends Mol Med 12: 17-25.

Wang J, Hendrix A, Hernot S, Lemaire M, De Bruyne E, Van Valckenborgh E, Lahoutte T, De Wever O, Vanderkerken K, Menu E. 2014. Bone marrow stromal cell-derived exosomes as communicators in drug resistance in multiple myeloma cells. Blood 124: 555-566.

Weitzmann MN, Roggia C, Toraldo G, Weitzmann L, Pacifici R. 2002. Increased production of IL-7 uncouples bone formation from bone resorption during estrogen deficiency. J Clin Invest 110: 1643-1650.

Wong BR, Rho J, Arron J, Robinson E, Orlinick J, Chao M, Kalachikov S, Cayani E, Bartlett FS, III, Frankel WN, et al. 1997. TRANCE is a novel ligand of the tumor necrosis factor receptor family that activates c-Jun $\mathrm{N}$-terminal kinase in T cells. J Biol Chem 272: 25190-25194.

Xiong J, O'Brien CA. 2012. Osteocyte RANKL: New insights into the control of bone remodeling. J Bone Miner Res 27: 499-505.

Yaccoby S, Pearse RN, Johnson CL, Barlogie B, Choi Y, Epstein J. 2002. Myeloma interacts with the bone marrow microenvironment to induce osteoclastogenesis and is dependent on osteoclast activity. Br J Haematol 116: 278-290.

Yaccoby S, Wezeman MJ, Henderson A, Cottler-Fox M, Yi Q, Barlogie B, Epstein J. 2004. Cancer and the microenvironment: Myeloma-osteoclast interactions as a model. Cancer Res 64: 2016-2023. 
Yaccoby S, Wezeman MJ, Zangari M, Walker R, Cottler-Fox M, Gaddy D, Ling W, Saha R, Barlogie B, Tricot G, et al. 2006. Inhibitory effects of osteoblasts and increased bone formation on myeloma in novel culture systems and a myelomatous mouse model. Haematologica 91: 192-199.

Yaccoby S, Ling W, Zhan F, Walker R, Barlogie B, Shaughnessy JD Jr. 2007. Antibody-based inhibition of DKK1 suppresses tumor-induced bone resorption and multiple myeloma growth in vivo. Blood 109: 2106-2111.

Yasuda H, Shima N, Nakagawa N, Yamaguchi K, Kinosaki M, Mochizuki S, Tomoyasu A, Yano K, Goto M, Murakami A, et al. 1998. Osteoclast differentiation factor is a ligand for osteoprotegerin/osteoclastogenesis-inhibitory factor and is identical to TRANCE/RANKL. Proc Natl Acad Sci 95: 3597-3602.

Yee AJ, Laubach JP, Nooka AK, O'Donnell EK, Weller EA, Couture NR, Wallace EE, Burke JN, Harrington CC, Puccio-Pick M, et al. 2015. Phase 1 dose-escalation study of sotatercept (ACE-011) in combination with lenalidomide and dexamethasone in patients with relapsed and/or refractory multiple myeloma. Blood 126: 4241.

Zangari M, Esseltine D, Lee CK, Barlogie B, Elice F, Burns MJ, Kang SH, Yaccoby S, Najarian K, Richardson P, et al. 2005. Response to bortezomib is associated to osteoblastic activation in patients with multiple myeloma. $\mathrm{Br} \mathrm{J} \mathrm{Hae-}$ matol 131: 71-73.

Zangari M, Aujay M, Zhan F, Hetherington KL, Berno T, Vij R, Jagannath S, Siegel D, Keith Stewart A, Wang L, et al. 2011. Alkaline phosphatase variation during carfilzomib treatment is associated with best response in multiple myeloma patients. Eur J Haematol 86: 484-487.

Zhou F, Meng S, Song H, Claret FX. 2013. Dickkopf-1 is a key regulator of myeloma bone disease: Opportunities and challenges for therapeutic intervention. Blood Rev 27: 261-267.

Zou W, Restifo NP. 2010. $\mathrm{T}_{\mathrm{H}} 17$ cells in tumour immunity and immunotherapy. Nat Rev Immunol 10: 248-256. 


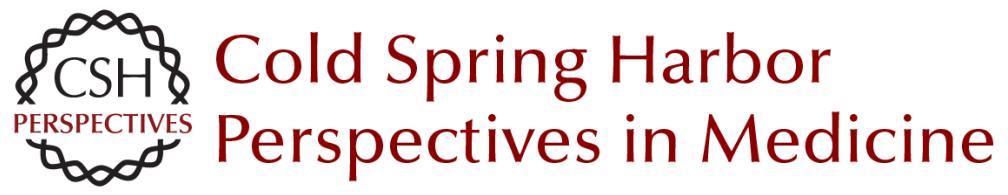

\section{Multiple Myeloma and Bone: The Fatal Interaction}

Silvia Marino and G. David Roodman

Cold Spring Harb Perspect Med 2018; doi: 10.1101/cshperspect.a031286 originally published online December 11, 2017

\section{Subject Collection Bone: A Regulator of Physiology}

\section{Mechanism of Bone Mineralization} Monzur Murshed

Neural Regulation of Bone and Bone Marrow Maria Maryanovich, Shoichiro Takeishi and Paul S. Frenette

Regulation of Bone Remodeling by Parathyroid Hormone Marc N. Wein and Henry M. Kronenberg

The Bone Marrow Microenvironment in Health and Myeloid Malignancy

Marta Galán-Díez, Álvaro Cuesta-Domínguez and Stavroula Kousteni

The Biology of Bone Metastasis

Mark Esposito, Theresa Guise and Yibin Kang

\section{Bone Remodeling and the Microbiome} Roberto Pacifici
Osteoimmunology
Kazuo Okamoto and Hiroshi Takayanagi

Multiple Myeloma and Bone: The Fatal Interaction Silvia Marino and G. David Roodman

Biology of Bone: The Vasculature of the Skeletal System

Emma C. Watson and Ralf H. Adams

Regulation of Energy Metabolism by

Bone-Derived Hormones

Paula Mera, Mathieu Ferron and Ioanna Mosialou

\section{Biology of Fibroblast Growth Factor 23: From \\ Physiology to Pathology \\ Marie Courbebaisse and Beate Lanske}

Regulation of Bone Metabolism by Sex Steroids Sundeep Khosla and David G. Monroe

For additional articles in this collection, see http://perspectivesinmedicine.cshlp.org/cgi/collection/ 